Prepared in cooperation with Clean Water Services and the Joint Water Commission

\title{
Upstream Factors Affecting Tualatin River Algae- Tracking the 2008 Anabaena Algae Bloom to Wapato Lake, Oregon
}

Scientific Investigations Report 2015-5178 
Cover: Wapato Lake, as seasonally flooded in winter. Photograph by Stewart Rounds, U.S. Geological Survey, January 27, 2015. 


\section{Upstream Factors Affecting Tualatin River Algae-Tracking the 2008 Anabaena Algae Bloom to Wapato Lake, Oregon}

By Stewart A. Rounds, Kurt D. Carpenter, Kristel J. Fesler, and Jessica L. Dorsey

Prepared in cooperation with Clean Water Services and the Joint Water Commission

Scientific Investigations Report 2015-5178 


\title{
U.S. Department of the Interior SALLY JEWELL, Secretary
}

\section{U.S. Geological Survey \\ Suzette M. Kimball, Acting Director}

\author{
U.S. Geological Survey, Reston, Virginia: 2015
}

For more information on the USGS - the Federal source for science about the Earth, its natural and living resources, natural hazards, and the environment—visit http://www.usgs.gov or call 1-888-ASK-USGS.

For an overview of USGS information products, including maps, imagery, and publications, visit http://www.usgs.gov/pubprod/.

Any use of trade, firm, or product names is for descriptive purposes only and does not imply endorsement by the U.S. Government.

Although this information product, for the most part, is in the public domain, it also may contain copyrighted materials as noted in the text. Permission to reproduce copyrighted items must be secured from the copyright owner.

Suggested citation:

Rounds, S.A., Carpenter, K.D., Fesler, K.J., and Dorsey, J.L., 2015, Upstream factors affecting Tualatin River algaeTracking the 2008 Anabaena algae bloom to Wapato Lake, Oregon: U.S. Geological Survey Scientific Investigations Report 2015-5178, 41 p., http://dx.doi.org/10.3133/sir20155178.

ISSN 2328-0328 (online) 


\section{Contents}

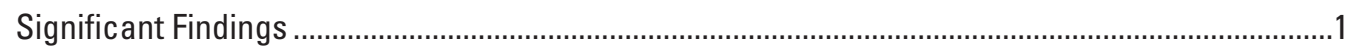

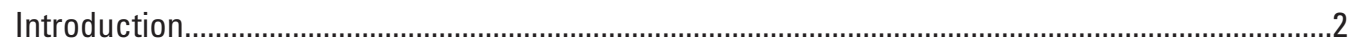

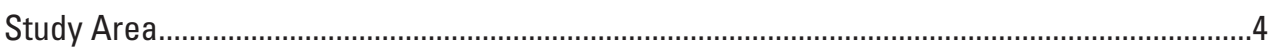

Study Objectives and Report Scope ...............................................................................

Overview of Reconstructed Sequence of Events..................................................................

Background and Context..................................................................................................

Data Sources, Methods, and Quality Assurance/Quality Control .................................................10

Continuous Water-Quality and Streamflow Monitors..........................................................10

Plankton-Sample Collection, Processing, and Identification ..................................................10

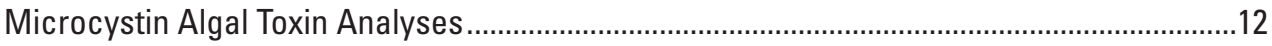

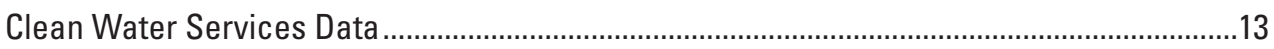

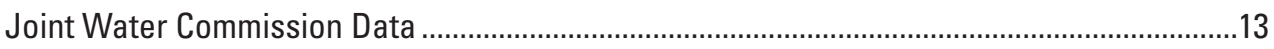

Oregon Department of Environmental Quality Data.............................................................13

Bloom Origination, Discovery, and Tracking to Wapato Lake .........................................................

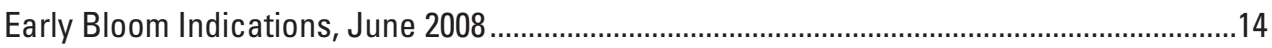

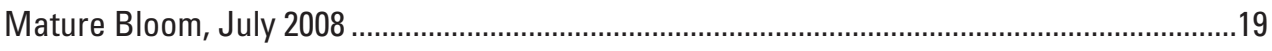

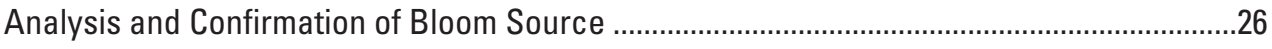

Upstream Factors Affect Downstream Tualatin River Algae......................................................29

Implications for Monitoring and Management.........................................................................30



Municipal Water Issues.....................................................................................................

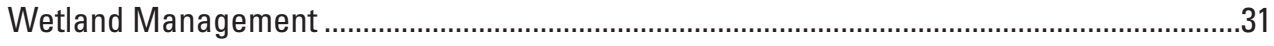

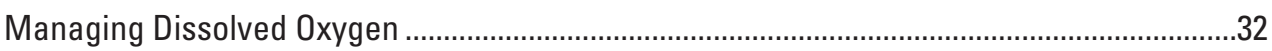

Water-Quality and Plankton Monitoring and Models ..........................................................32

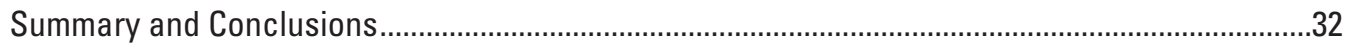

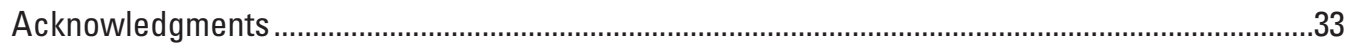

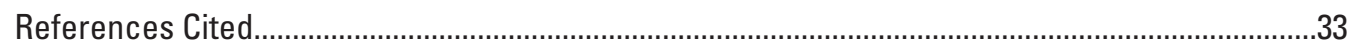

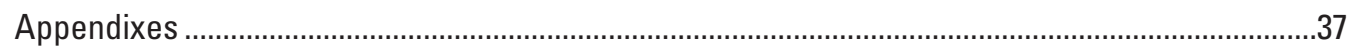

Appendix A. Additional Water-Quality Data from Clean Water Services for Selected Sites in the Tualatin River, Oregon, May-August 2008 ...............................................37

Appendix B. Biovolume of Algal Taxa in Water Samples Collected from Wapato Lake Pump Discharge and Downstream in the Tualatin River at the Spring Hill Pumping Plant, Oregon, July 19-21, 2008. 


\section{Figures}

1. Map showing Tualatin River basin, northwestern Oregon ................................................

2. Photograph showing a partially drained Wapato Lake, Oregon..........................................

3. Photograph showing Wapato Lake, Oregon, viewed from the west .................................3

4. Map showing sampling sites and streamgage locations, Tualatin River

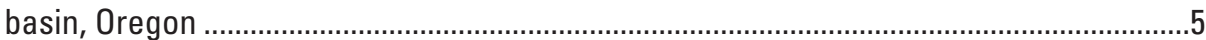

5. Map showing sampling sites in and near the Wapato Lake agricultural area in the upper Tualatin River basin, Oregon ......................................................................6

6. Photograph showing breached dike before repair, west side of Wapato Lake, Oregon....................................................................................................

7. Photograph showing repaired levee separating Wapato Lake and Wapato Creek on the west side of Wapato Lake, Oregon ..

8. Photograph showing algal bloom and duckweed in the internal canal leading to the pump house at Wapato Lake, Oregon .8

9. Photographs showing Wapato Improvement District's pump house discharge from Wapato Lake, Oregon and dead fish in the discharge pool. .8

10. Photographs showing floating mats of blue-green algae in the Tualatin River upstream of Stafford Road and microscopic views of a colony and filament of Anabaena in the Tualatin River, Oregon.

11. Graph showing estimated discharge from the Wapato Creek drainage, as estimated from a mass balance of measured streamflows in Scoggins Creek and the Tualatin River, Oregon, June-July 2008.

12. Graph showing total organic carbon concentrations in the Tualatin River at the Spring Hill pumping plant, Oregon, March-July 2008

13. Graphs showing longitudinal pattern in Anabaena flos-aquae abundance and chlorophyll- $a$ concentrations in the Tualatin River along with measurements from the Wapato Lake pump discharge, Oregon, July 2008.

14. Graph showing comparison of measured dissolved oxygen percent saturation in the Tualatin River near Scholls, Oregon in 2008 with long-term conditions in 1997-2012.

15. Graph showing dissolved-oxygen percent saturation in the Tualatin River at river miles 24.5, 9.9, and 3.4, showing a substantial increase in dissolved oxygen associated with the arrival of the Anabaena bloom at each location, Tualatin River, Oregon, July 2008.

16. Boxplots showing comparison of chlorophyll- $a$ and total phosphorus concentrations in the Tualatin River, Oregon, July 2005-07 and July 2008 


\section{Tables}

1. Data sources and water-quality constituents analyzed in river water and finished drinking water at selected sites in the Tualatin River basin, Oregon, 2008

2. Selected sampling sites and data collection activities in the Tualatin River basin, Oregon, 2006-08.

3. Reconstructed timeline of events associated with the bloom of Anabaena flos-aquae in Wapato Lake and downstream in the Tualatin River, Oregon, 2008...........14

4. Water-quality data from the Joint Water Commission for sites in the upper Tualatin River basin, Oregon, May-August 2008.

5. Chlorophyll and total phosphorus data from Clean Water Services for sites in the Tualatin River, Oregon, May-August 2008.

6. Anabaena flos-aquae cell counts and microcystin algal toxin concentrations for select sites in the Tualatin River basin, Oregon, June-August 2008

7. Results of water-quality tests on samples of Wapato Lake pump discharge compared with nearby locations, upper Tualatin River basin, July 19 and 21, 2008

8. Ten most abundant algal taxa in Wapato Lake pump discharge and abundances downstream in the Tualatin River at the JWC/TVID Spring Hill pumping plant, Oregon, July 19 and $21,2008$.

9. Zooplankton taxa in water samples collected from Wapato Lake pump discharge and downstream in the Tualatin River at the JWC/TVID Spring Hill pumping plant, Oregon, July 19 and 21, 2008

10. Water-quality data from the Oregon Department of Environmental Quality for selected sites in the upper Tualatin River basin, Oregon, August 2008. 


\section{Conversion Factors}

Inch/Pound to International System of Units

\begin{tabular}{lcl}
\hline \multicolumn{1}{c}{ Multiply } & \multicolumn{1}{c}{ By } & \multicolumn{1}{c}{ To obtain } \\
\hline inch (in.) & Length & \\
foot (ft) & 2.54 & centimeter $(\mathrm{cm})$ \\
mile (mi) & 0.3048 & meter (m) \\
& 1.609 & kilometer $(\mathrm{km})$ \\
\hline million gallons (Mgal) & Volume & \\
acre-foot (acre-ft) & 3,785 & cubic meter $\left(\mathrm{m}^{3}\right)$ \\
& 1,233 & cubic meter $\left(\mathrm{m}^{3}\right)$ \\
\hline cubic foot per second (ft $3 / \mathrm{s})$ & Flow rate & \\
gallon per minute (gal/min) & 0.02832 & cubic meter per second $\left(\mathrm{m}^{3} / \mathrm{s}\right)$ \\
million gallons per day (Mgal/d) & 0.06309 & liter per second $(\mathrm{L} / \mathrm{s})$ \\
\hline
\end{tabular}

International System of Units to Inch/Pound

\begin{tabular}{|c|c|c|}
\hline Multiply & By & To obtain \\
\hline \multicolumn{3}{|c|}{ Length } \\
\hline meter (m) & 3.281 & foot (ft) \\
\hline kilometer (km) & 0.6214 & mile (mi) \\
\hline \multicolumn{3}{|c|}{ Area } \\
\hline square meter $\left(\mathrm{m}^{2}\right)$ & 0.0002471 & acre \\
\hline square meter $\left(\mathrm{m}^{2}\right)$ & 10.76 & square foot $\left(\mathrm{ft}^{2}\right)$ \\
\hline \multicolumn{3}{|c|}{ Volume } \\
\hline cubic meter (m³) & 0.0002642 & million gallons (Mgal) \\
\hline cubic meter $\left(\mathrm{m}^{3}\right)$ & 35.31 & cubic foot $\left(\mathrm{ft}^{3}\right)$ \\
\hline cubic meter $\left(\mathrm{m}^{3}\right)$ & 0.0008107 & acre-foot (acre-ft) \\
\hline \multicolumn{3}{|c|}{ Flow rate } \\
\hline cubic meter per second $\left(\mathrm{m}^{3} / \mathrm{s}\right)$ & 35.31 & cubic foot per second $\left(\mathrm{ft}^{3} / \mathrm{s}\right)$ \\
\hline \multicolumn{3}{|c|}{ Mass } \\
\hline kilogram (kg) & 2.205 & pound avoirdupois (lb) \\
\hline kilogram per day (kg/d) & 2.205 & pound per day (lb/d) \\
\hline
\end{tabular}

Temperature in degrees Celsius $\left({ }^{\circ} \mathrm{C}\right)$ may be converted to degrees Fahrenheit $\left({ }^{\circ} \mathrm{F}\right)$ as follows:

$$
{ }^{\circ} \mathrm{F}=\left(1.8 x^{\circ} \mathrm{C}\right)+32 .
$$

\section{Datum}

Horizontal coordinate information is referenced to the North American Datum of 1983 (NAD 83). 


\title{
Supplemental Information
}

Algal cell densities for phytoplankton are given in cells per milliliter of sample (cells $/ \mathrm{mL}$ ), and zooplankton densities are given in number of organisms per cubic meter $\left(\# / \mathrm{m}^{3}\right)$. Algal cell biovolumes are given in cubic microns per milliliter $\left(\mu \mathrm{m}^{3} / \mathrm{mL}\right)$.

Specific conductance is given in microsiemens per centimeter at 25 degrees Celsius $(\mu \mathrm{S} / \mathrm{cm}$ at $\left.25^{\circ} \mathrm{C}\right)$.

Concentrations of chemical constituents in water are given in either milligrams per liter (mg/L), micrograms per liter $(\mu \mathrm{g} / \mathrm{L})$, or nanograms per liter $(\mathrm{ng} / \mathrm{L})$.

\section{Abbreviations and Acronyms}

\author{
BOD biochemical oxygen demand \\ COD chemical oxygen demand \\ CWS Clean Water Services \\ DO dissolved oxygen \\ ELISA enzyme-linked immunosorbent assay \\ EPA U.S. Environmental Protection Agency \\ JWC Joint Water Commission \\ MIB methyl isoborneol \\ ODEO Oregon Department of Environmental Quality \\ OWRD Oregon Water Resources Department \\ QA quality assurance \\ RM river mile \\ SPME solid-phase micro-extraction \\ SRS USGS Standard Reference Sample program \\ TOC total organic carbon \\ TVID Tualatin Valley Irrigation District \\ USGS U.S. Geological Survey \\ WTP water treatment plant \\ WWTF wastewater treatment facility
}





\title{
Upstream Factors Affecting Tualatin River Algae- Tracking the 2008 Anabaena Algae Bloom to Wapato Lake, Oregon
}

\author{
By Stewart Rounds', Kurt Carpenter ${ }^{1}$, Kristel Fesler ${ }^{2}$, and Jessica Dorsey ${ }^{2}$
}

\section{Significant Findings}

- A large bloom that included floating mats of the bluegreen algae Anabaena flos-aquae occurred in the lower 20 miles of the Tualatin River in northwestern Oregon between July 7 and July 17, 2008.

- The floating bloom was deemed a hazard to recreational users of the river due to the potential production of algal toxins (anatoxin- $a$ and microcystin), and a public health advisory was posted for the lower 10.8 miles of the river by the Oregon Department of Human Services for July 12-25, 2008.

- The bloom caused nuisance taste and odor issues and required modified drinking-water treatment techniques where water was withdrawn for municipal uses in the upper reaches of the Tualatin River, some 46 miles upstream of the worst algae problems.

- Using water sample data from Clean Water Services and the Joint Water Commission, and continuous and discrete monitoring data from the U.S. Geological Survey, the source of the anomalous water-quality conditions and the likely source of the Anabaena bloom was traced upstream to discharges from the Wapato Lake agricultural area near Gaston, Oregon, in the upper part of the watershed near river mile 60 .
- The Wapato Lake algae bloom occurred as standing water remained on the lakebed far longer than normal —into early summer. A failure of the levee on the edge of Wapato Lake in December 2007 caused by heavy rainfall and high water in the canal outside the levee inundated the lakebed to a depth of 7-9 feet, storing thousands of acre-feet more water than its normal winter volume. The water could not be pumped out until the levee was repaired or river levels receded, thus delaying drainage of the lake until summer and facilitating the bloom.

- In normal summers, the lower Tualatin River grows a moderate crop of algae that responds strongly to streamflow (residence time), light available for photosynthesis, and phosphorus concentrations. In 2008, however, inoculation of the river with phytoplankton and zooplankton discharged from Wapato Lake some 30 miles upstream of the lower, pooled reach of the river demonstrated the importance of upstream factors on plankton communities and water-quality conditions in the Tualatin River.

- The Wapato Lake algae bloom of July 2008 provided useful information and lessons for agencies managing public health, wetlands, agricultural activities, and water quality in the Tualatin River basin and similar river basins elsewhere.

- The results and insights derived from this study can be used to enhance future monitoring and data collection strategies designed to improve water quality and plankton models and better predict dissolved-oxygen concentrations in the lower Tualatin River. 


\section{Introduction}

In early July 2008, a large blue-green algae bloom was discovered in the lower Tualatin River, which is a tributary to the Willamette River in northwestern Oregon (fig. 1). Although floating algal mats had occurred approximately 30 years prior, this bloom was the worst in memory for many water-quality scientists and managers familiar with the Tualatin River. This slow-moving, warm, and nutrientenriched section of river has a long history of water-quality problems related to summertime algal blooms through the 1980s. Upgrades in wastewater treatment in the early 1990s greatly diminished the severity of the blooms by capping nutrient levels, and flow augmentation from upstream reservoirs has added dilution and increased water velocity that reduces the time available for blooms to develop. The 2008 bloom, though, was different in many ways.
In June 2008, the Joint Water Commission (JWC) was working to identify the source of anomalous tastes and odors in its drinking-water supply, which is drawn from the Tualatin River at the Spring Hill pumping plant at river mile (RM) 56.1. In early July 2008, sampling crews from Clean Water Services (CWS) and the U.S. Geological Survey (USGS), as well as members of the Tualatin Riverkeepers advocacy group, reported seeing a distinct algal bloom in the lower river between Elsner (Roy Rogers Road, RM 16.2) and Stafford Road (RM 5.5). The bloom included thick surface accumulations and shoreline scums. Samples were collected and examined microscopically, revealing that the bloom and floating mats were composed primarily of Anabaena flosaquae - a colonial blue-green algae that is considered to be a nuisance species because (1) it often forms surface scums and floating mats, (2) it is capable of producing nerve and liver toxins that pose a potential public health hazard to recreational


EXPLANATION

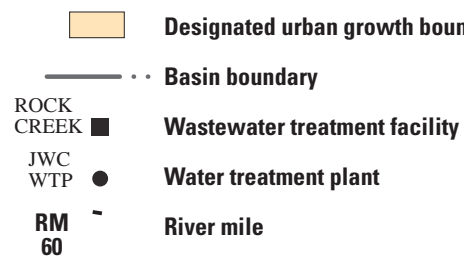

Figure 1. Tualatin River basin, northwestern Oregon. 
water users and drinking water supplies, and (3) it can produce nuisance taste and odor compounds that are difficult for drinking water treatment plants to remove. Given the presence of surface scums and the dominance of a potentially toxigenic species in an area of the river where recreational users are known to visit, the Public Health Division of the Oregon Department of Human Services (now part of the Oregon Health Authority) issued a public health advisory for the lower Tualatin River from Jurgens Park (RM 10.8) downstream to the river mouth on July 12, 2008 (Bonn, 2008).

To identify the longitudinal extent and source of the bloom, JWC along with CWS and USGS relied on data from a network of continuous water-quality monitors and streamgages in the river and its tributaries and initiated additional sampling. Results indicated that the source of the blue-green algae bloom was drainage water from Wapato Lake near Gaston, Oregon (figs. 1-3). A bloom had developed in the shallow lake, and pumps used to drain the lake for farming conveyed enough algal biomass and nutrients into Wapato Creek and downstream to the Tualatin River to initiate a riverine algae population that not only persisted, but thrived in the nutrientenriched water, multiplying into a large bloom resembling a thick green chowder in parts of the lower reservoir-like reach of the Tualatin River some 50 mi downstream.

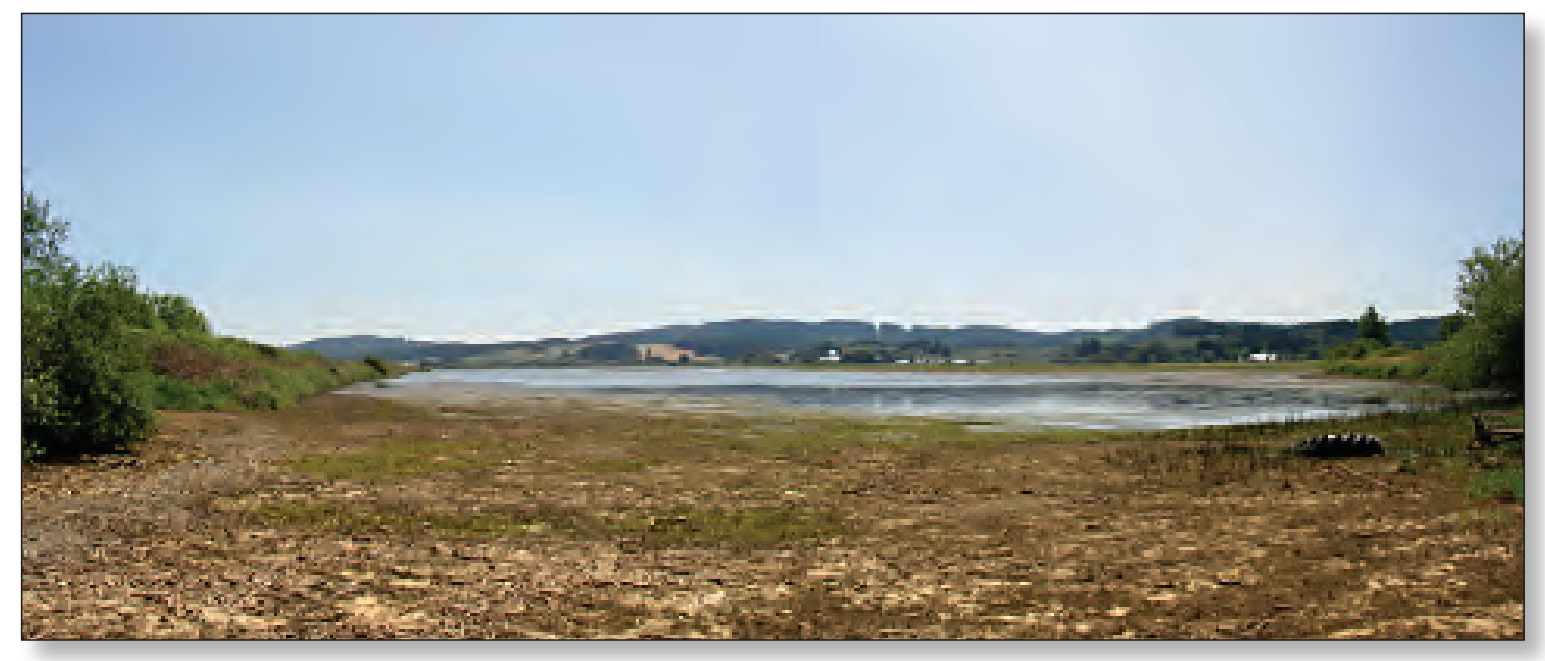

Figure 2. A partially drained Wapato Lake, Oregon. (Photograph taken by Stewart Rounds, U.S. Geological Survey, July 19, 2008.)

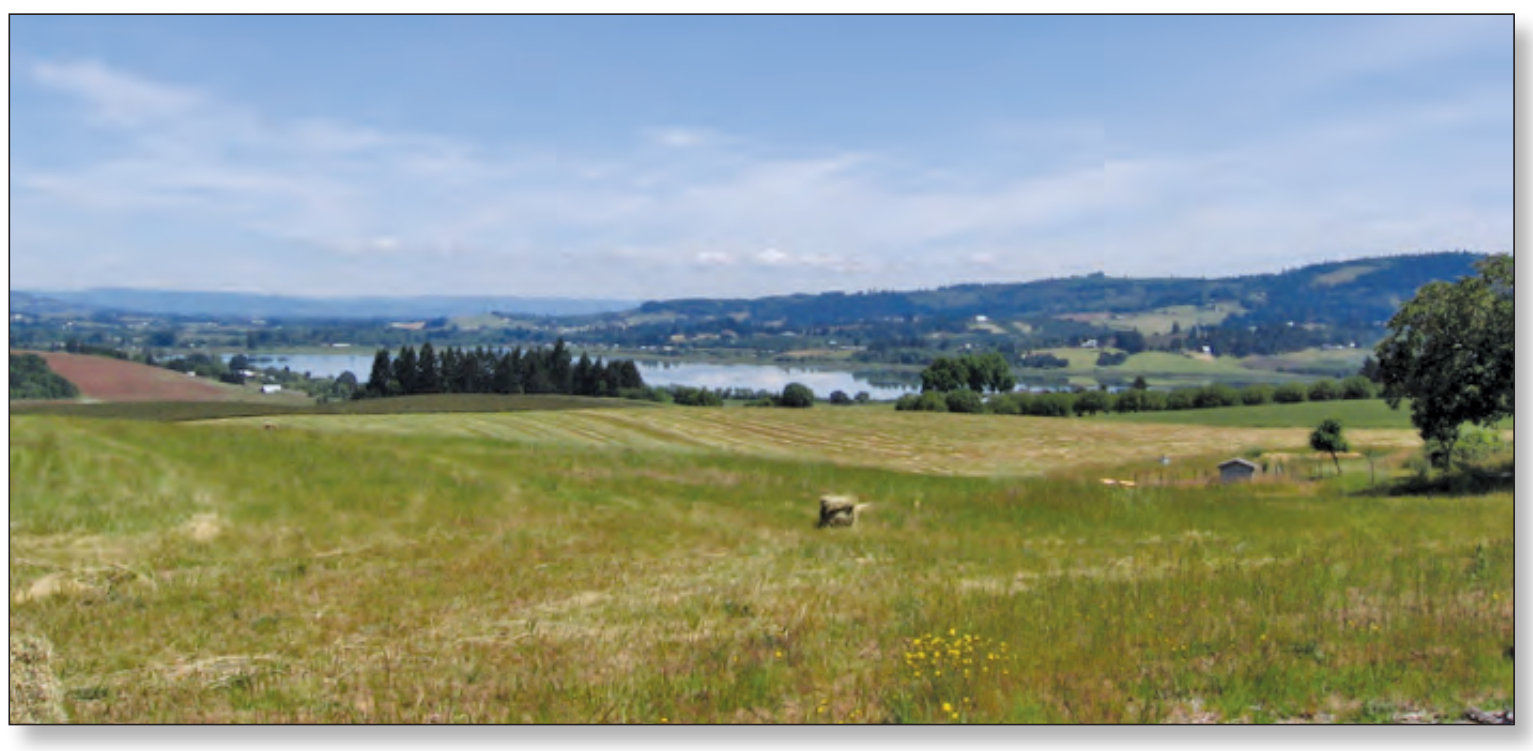

Figure 3. Wapato Lake, Oregon, viewed from the west. (Photograph taken by Matt Nussbaumer, City of Hillsboro, June 25, 2008.) 
The series of events related to the 2008 Wapato Lake algal boom demonstrates the importance of upstream inoculation, or seeding, as one of the factors controlling phytoplankton (free-floating algae) populations in the Tualatin River, a concept that was previously described for this river by Carpenter and Rounds (2013). Although other studies and modeling efforts have shown that phytoplankton populations in the Tualatin River are largely controlled by streamflow, light, and phosphorus concentrations, the 2008 bloom demonstrated that periodic inputs of viable algal cells from wetland drainage, nursery ponds, reservoirs, or other sources can greatly influence the composition and abundance of phytoplankton in the Tualatin River. This process is critical to understand because although phytoplankton photosynthesis is important for maintaining minimum dissolved-oxygen (DO) concentrations in the lower river, a population crash of a large algal bloom can deplete DO to critical levels that may harm fish and other aquatic life in the river during the summer low-flow period, often when temperatures are at or near their seasonal maximum. Anabaena blooms also can produce and release toxins that can affect aquatic life, pose a public health hazard for direct contact and consumption, and be a drinking-water nuisance.

\section{Study Area}

The study area consists of the Tualatin River and Wapato Lake in northwestern Oregon (fig. 1). The Tualatin River begins in the Coast Range and flows generally east, meandering across a fertile valley before joining the Willamette River south of Portland. The river reach of particular interest in this study extends from the Old Highway 47 bridge in the city of Gaston (RM 62.3) just upstream of the Wapato Lake diversion and continues downstream to the Oswego Dam (RM 3.4, fig. 4). Several continuous waterquality monitors and streamgages are located in this 58.9-mi river reach. Water-quality data from water samples collected by several agencies also are available from a dozen or so routine monitoring sites along the Tualatin River from Cherry Grove (RM 67.8) upstream of the Wapato Lake area to near the river's mouth.

Land use in the Tualatin River basin consists of forestry in the headwater tributaries, agriculture in the valley lowlands, and urban areas that are home to 550,000 people (U.S. Census Bureau, 2012) on the west side of the Portland, Oregon metropolitan area. Northwest Oregon tends to have warm and dry summers that result in seasonally low flow during summer and early autumn. Coincident with ample sunshine and sufficient nutrients in most summers, the low-flow season can produce moderate algal blooms in the "reservoir reach" of the Tualatin River. Compared to upstream reaches, the reservoir reach is defined as a deeper, wider, and slower river reach between RMs 30 and 3.4 that has the characteristics of a long, narrow lake with a 7-10 day residence time in summer. In the absence of much algae in this reach (for example, $<5 \mu \mathrm{g} / \mathrm{L}$ chlorophyll- $a$ ), photosynthetic production of DO is insufficient to offset oxygen demands from decomposing organic materials in river sediments, resulting in low-DO conditions that may persist for weeks or even months in summer and early autumn until rainfall, higher flow, or cooler temperatures improve conditions.

Flow in the Tualatin River is augmented for multiple purposes by water releases from Henry Hagg Lake on Scoggins Creek and Barney Reservoir in the adjoining Trask River system (made through an interbasin diversion into the headwaters of the Tualatin River) (fig. 1). Some of those releases are withdrawn at the Spring Hill pumping plant at RM 56.1, which serves the Tualatin Valley Irrigation District (TVID) and JWC. The JWC is a collective drinking-water supply agency formed between the cities of Hillsboro (the managing agency), Forest Grove, Beaverton, and the Tualatin Valley Water District. JWC and its partners provide wholesale water to the cities of North Plains, Cornelius, and Gaston. JWC operates the largest conventional water-treatment plant in Oregon, relying on processes such as flocculation, sedimentation, and filtration to produce as much as $75 \mathrm{Mgal}$ of drinking water each day to serve more than 300,000 people.

Clean Water Services is the primary stormwater- and wastewater-management utility for the urban areas of Washington County and treats wastewater from most of the basin's population. Wastewater treatment occurs at two small and two large facilities, but only the two large wastewater-treatment facilities (WWTFs), Rock Creek and Durham, at RMs 38.1 and 9.3, respectively, discharged effluent to the Tualatin River during summer for the period of this study. These WWTFs were upgraded in the early 1990s to meet stringent summertime effluent load limits for ammonia and phosphorus. In recent years (2006-08), treated effluent from these two WWTFs during summer contained comparatively small concentrations of dissolved ammonianitrogen (0.03-0.07 $\mathrm{mg} / \mathrm{L})$ and soluble reactive phosphorus (0.013-0.018 mg/L) (median concentrations), whereas nitrate-nitrogen concentrations in effluent were considerably higher (10-15 mg/L; Carpenter and Rounds, 2013, table 4). Although nitrogen concentrations are elevated, phosphorus concentrations at times are low enough to limit phytoplankton growth and may initiate algal population crashes (Carpenter and Rounds, 2013). 




\section{EXPLANATION}

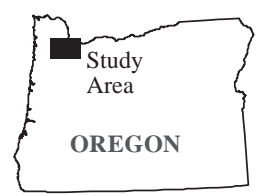

\section{Designated urban growth boundary (2010)}

Sampling site and map No.

Tualatin River at Weiss Bridge (RM 0.2)

Tualatin River at Oswego Dam (RM 3.4)

Tualatin River downstream of Stafford Road (RM 5.5)

Tualatin River at Boones Ferry Road (RM 8.7)

Tualatin River downstream of Fanno Creek and Durham WWTF (RM 9.2)

Tualatin River downstream of Cook Park (RM 9.7)

Tualatin River at RM 9.9 near Tualatin (RM 9.9)

Tualatin River at Jurgens Park (RM 10.8)

Tualatin River at Elsner (Roy Rogers Road) (RM 16.2)

Tualatin River near Scholls (RM 24.5)

Tualatin River at Scholls Bridge (RM 26.9)

Tualatin River at Farmington (RM 33.3)

Tualatin River at Rood Bridge (RM 38.4)

Tualatin River at Highway 219 Bridge (RM 44.4)

Tualatin River at Golf Course Road (RM 51.5)

Tualatin River at JWC/TVID Spring Hill Pumping Plant Intake (RM 56.1)

Tualatin River at Dilley (Spring Hill Road) (RM 58.8)

Wapato Creek at Gaston Road (includes Wapato Lake pump discharge)

Tualatin River at Wapato Improvement District headgate (RM 61.9)

Tualatin River at the Old Highway 47 Bridge (Gaston) (RM 62.3)

Tualatin River at Cherry Grove (RM 67.8)

CREEK Wastewater treatment facility

JWC

RM -

60

Water treatment plant

River mile

Figure 4. Sampling sites and streamgage locations, Tualatin River basin, Oregon. 
The Wapato Lake agricultural area near Gaston (fig. 5) includes a 730-acre lake and wetland that historically supported a wild crop of wapato, a potato-like bulb considered a "First Food" of Native Americans. Winter rains once expanded the seasonally inundated area to nearly 1,500 acres, creating an extensive wetland with scrub-shrub plant communities that supported large numbers of resident and migrating bird populations and waterfowl (U.S. Fish and Wildlife Service, 2007; Clean Water Services, 2010). The soils of the lakebed are known as Labish mucky clay, a type of soil that is relatively rich in organic matter and nutrients (Green, 1982). By 1895, efforts to drain Wapato Lake and use the lakebed for agriculture had begun through the installation of drainage canals (Cass and Miner, 1993). In the 1930s, a levee and pump system was constructed around Wapato Lake. The system allowed farmers of the Wapato Improvement District to divert tributary creeks around the lake and drain the lake each spring so that the rich lakebed soils could be farmed for
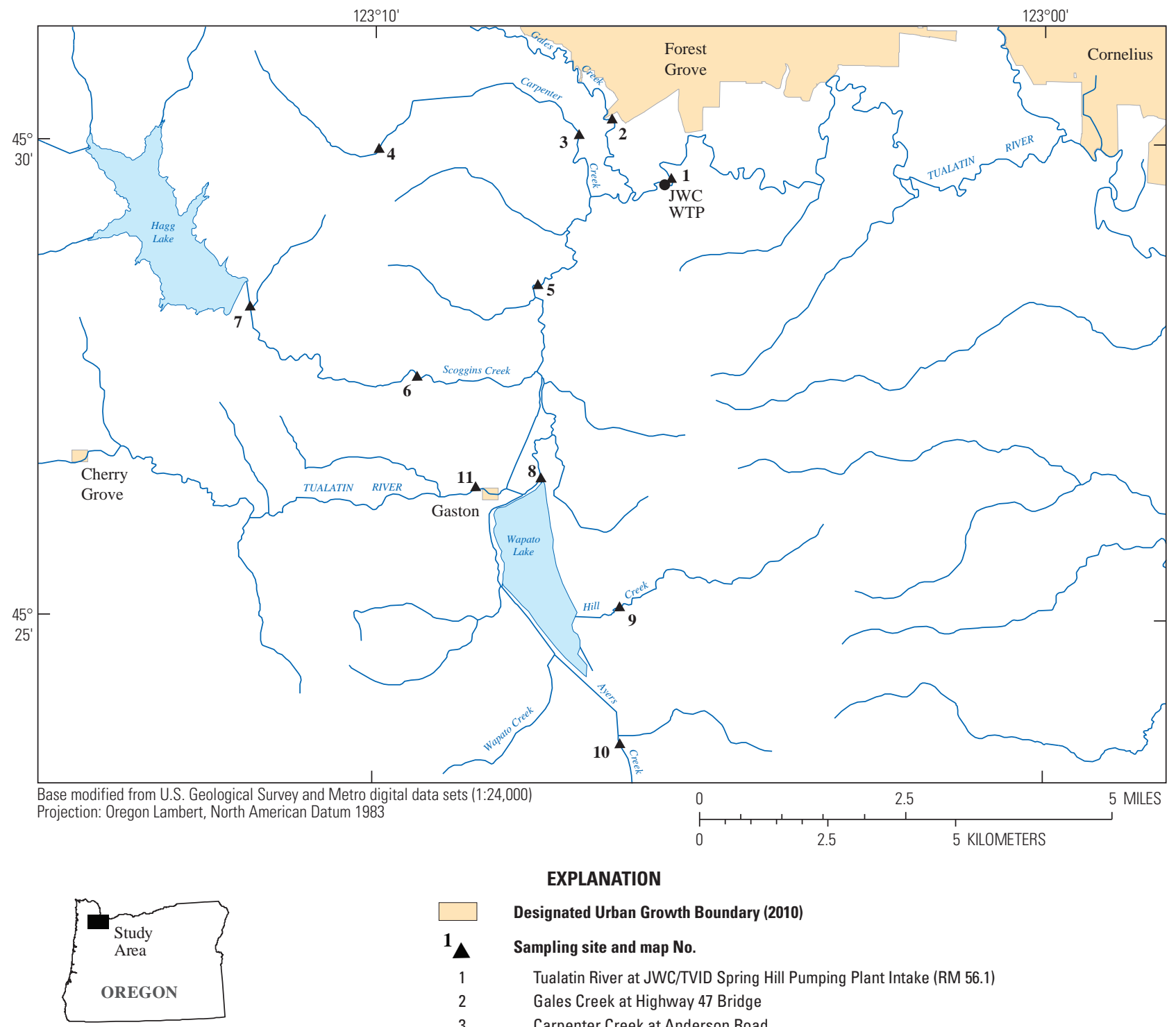

EXPLANATION

Designated Urban Growth Boundary (2010)

Sampling site and map №.

Tualatin River at JWC/TVID Spring Hill Pumping Plant Intake (RM 56.1)

Gales Creek at Highway 47 Bridge

Carpenter Creek at Anderson Road

Carpenter Creek at Plum Lee Road

Tualatin River at Dilley (RM 58.8)

Scoggins Creek at Old Highway 47

Scoggins Creek below Hagg Lake

Wapato Creek at Gaston Road

Hill Creek at Spring Hill Road

Ayers Creek at Northeast Flett Road

Tualatin River at Old Highway 47 Bridge (RM 62.3)

JWC $\bullet \quad$ Water treatment plant

Figure 5. Sampling sites in and near the Wapato Lake agricultural area in the upper Tualatin River basin, Oregon. 
onions and other crops. Irrigation water was delivered through a diversion at RM 61.9 on the Tualatin River. Water pumped out of the lake flows into Wapato Creek, which flows north for about 1 mile until it joins the Tualatin River at RM 60.1. The Spring Hill pumping plant that feeds the JWC WTP is located at RM 56.1, only 4.0 mi downstream of the confluence of Wapato Creek with the Tualatin River. In 2008, the U.S. Fish and Wildlife Service began to purchase parcels of the lakebed inside the levees and now manages the area as the Wapato Lake National Wildlife Refuge. During the period of interest in 2007-08, however, the area was still managed by the Wapato Improvement District.

\section{Study Objectives and Report Scope}

The objectives of this investigation were to:

(1) characterize and document water-quality conditions associated with the 2008 blue-green algae bloom in the Tualatin River; (2) identify the cause(s) of the bloom; (3) examine how water discharges from Wapato Lake affected plankton communities in the Tualatin River; and (4) document how the bloom affected municipal water providers and users.

This report documents the sequence of events of the 2008 blue-green algae bloom in the Tualatin River, including how the source was tracked to discharges from Wapato Lake, and describes the downstream response using readily available data and previously published accounts of the bloom (Bonn, 2008; Oregon Department of Environmental Quality, 2009). The report also includes suggestions and insights for future research, management, and monitoring activities aimed at a more refined characterization of factors that control phytoplankton in the river, including upstream discharges of plankton inocula.

The study focused on June through early August 2008, with particular emphasis on July when the bloom occurred in the lower river. Although the emphasis here is on 2008, knowledge gained from data gathered since the early 1990s was useful in understanding the 2008 event. This report reiterates some relevant findings presented by Carpenter and Rounds (2013), and readers are referred to that report for more detailed information on the plankton assemblages and factors that influence their abundance and composition in the Tualatin River.

\section{Overview of Reconstructed Sequence of Events}

On December 2-3, 2007, more than 6 in. of rainfall were recorded at several weather stations across the Tualatin River basin, causing near-flood levels in the Tualatin River at Gaston (RM 62.3) and Dilley (RM 58.8). The peak streamflow at Dilley was nearly $10,000 \mathrm{ft}^{3} / \mathrm{s}$ - almost identical to the peak streamflow recorded during the large flood of February 1996. During these high-water conditions, a small section of the aging levee on the west side of Wapato Lake failed

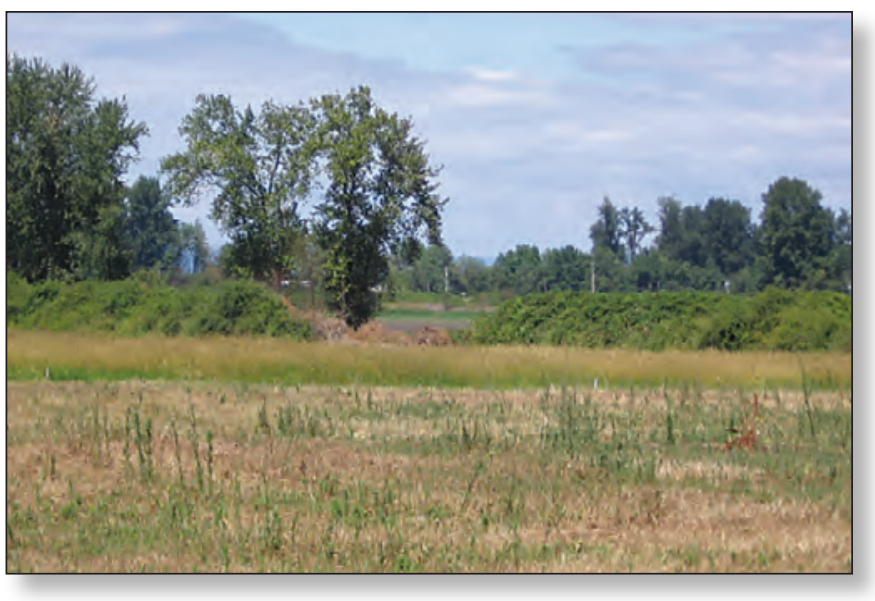

Figure 6. Breached dike before repair, west side of Wapato Lake, Oregon. (Photograph taken by Matt Nussbaumer, City of Hillsboro, July 30, 2008.)

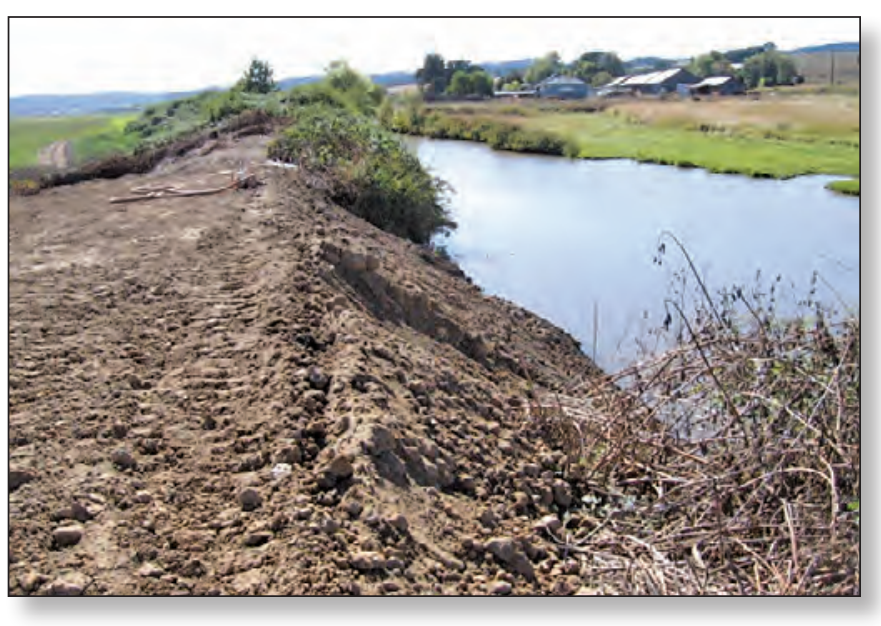

Figure 7. Repaired levee separating Wapato Lake and Wapato Creek on the west side of Wapato Lake, Oregon. (Photograph taken by Matt Nussbaumer, City of Hillsboro, September 23, 2008.)

(figs. 6-7), causing water to inundate the lakebed to a depth of approximately 7-9 ft. The levees normally keep water levels in the lake low by diverting tributaries around the outside of the lake and restricting inflows to rainfall, groundwater seepage, and some leakage through the levees. Without first repairing or temporarily patching the levee, Wapato Improvement District personnel could not pump flood waters out of the lake because discharges would return to the lake through the levee breach. The breach could not, however, be repaired because high water levels prevented access. Consequently, the lake was not drained in early spring as usual, and water remained ponded on the lakebed until early summer when river levels finally receded enough to render the breach inconsequential. The levee may or may not have been temporarily patched in early June, but a full levee repair was completed in early September 2008. 
As water remained on the lakebed into early summer, the water warmed, became nutrient-enriched, and developed a bloom of algae (fig. 8). Some water likely left the lake through the levee breach as river levels began to recede. Once water levels dropped below the levee breach, pumps were turned on and the algae-laden and nutrient-rich lake water was discharged to Wapato Creek and then downstream to the Tualatin River at RM 60.1. During pumping, a number of dead fish (carp, catfish, bluegill, and perch) were observed (fig. 9) that presumably had entered the lake with the floodwaters. These fish may have died as a result of warm temperatures, low DO concentrations, or injuries sustained while passing through the pumps (Oregon Department of Environmental Quality, 2008).

The Wapato Lake discharge was the likely cause of nuisance surface scums of algae many miles downstream (fig. 10) and a contributor to low-DO conditions later that summer (Carpenter and Rounds, 2013, table 14). Algal growth in Wapato Lake was the likely source of geosmin and organic carbon that required additional treatment by JWC's water treatment plant. Geosmin has a taste and smell that often is described as "earthy" or "musty," and is resistant to oxidation by the conventional drinking water treatment methods typically used by the JWC WTP (Izaguirre and others, 1982), potentially resulting in drinking water with an objectionable taste and smell.



Figure 8. Algal bloom and duckweed in the internal canal leading to the pump house at Wapato Lake, Oregon. (Photograph taken by Matt Nussbaumer, City of Hillsboro, on June 18, 2008.)
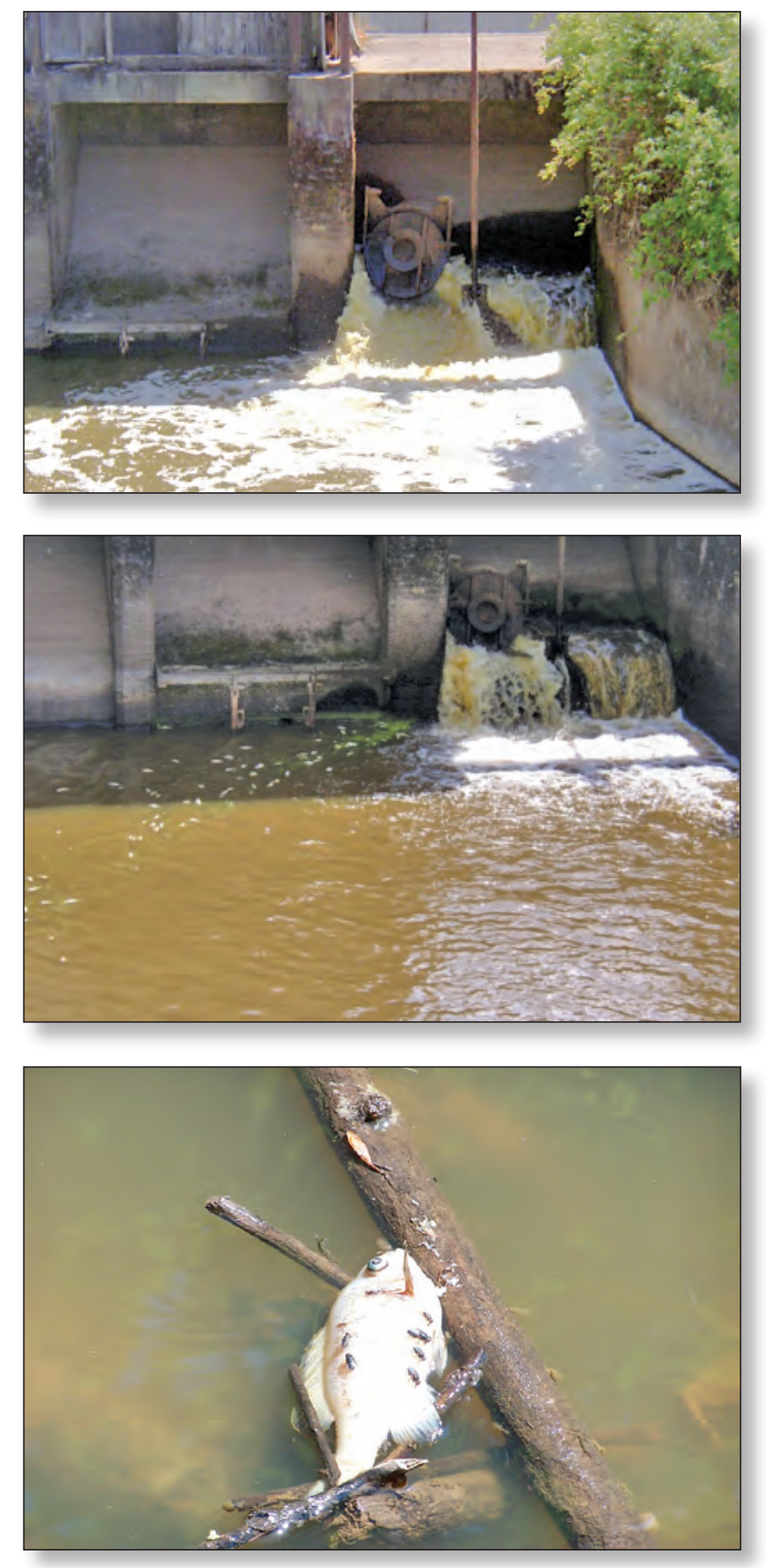

Figure 9. Wapato Improvement District's pump house discharge from Wapato Lake, Oregon $(A-B)$ and dead fish in the discharge pool $(B-C)$. (Photographs $A$ and $B$ taken by Stewart $A$. Rounds, U.S. Geological Survey, August 8, 2008; photograph $C$ courtesy of the U.S. Fish and Wildlife Service.) 

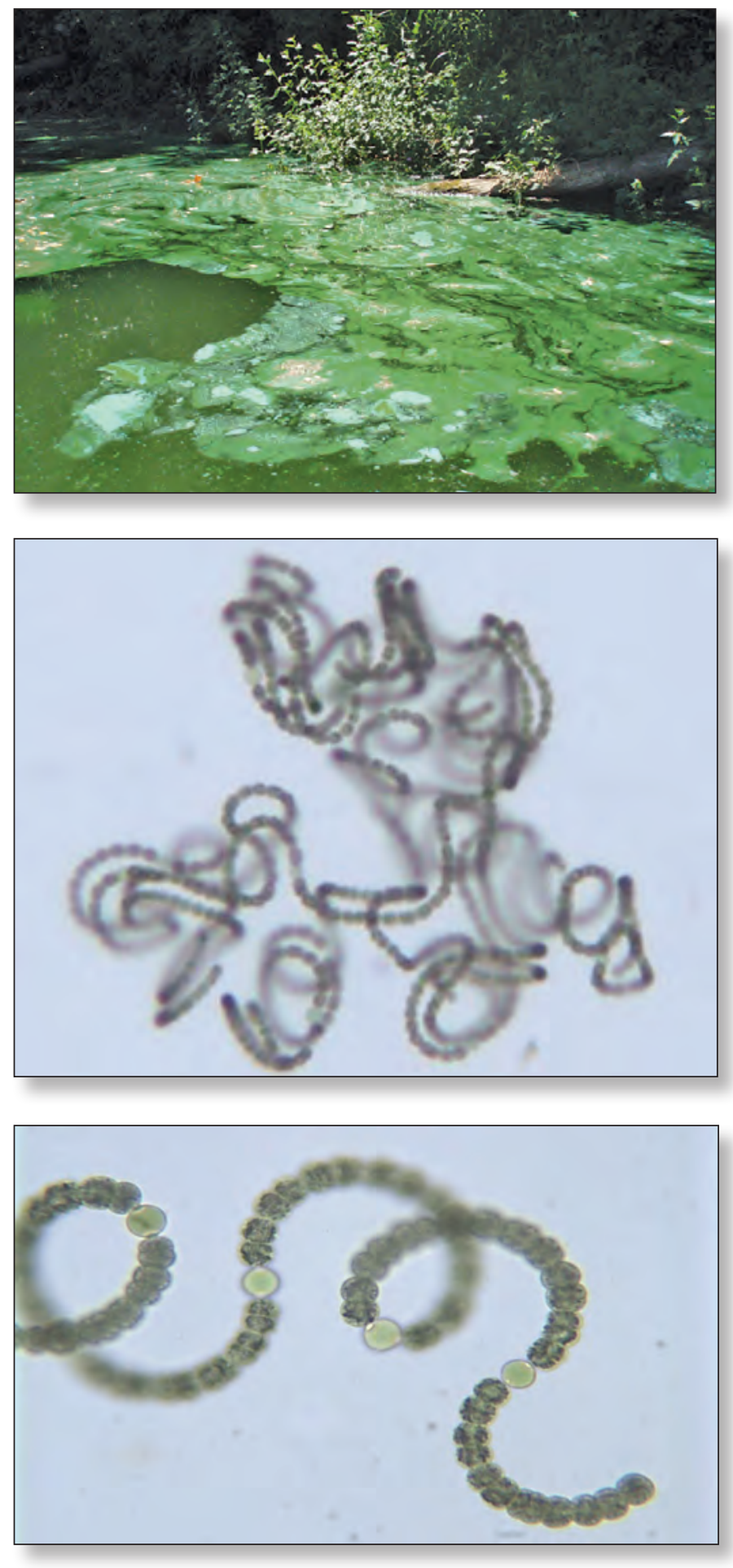

Figure 10. Floating mats of blue-green algae (Anabaena flosaquae) in the Tualatin River upstream of Stafford Road $(A)$ and microscopic views of a colony $(B)$ and filament of Anabaena $(C)$ in the Tualatin River, Oregon. (Photograph $A$ taken by Brian Wegener, Tualatin Riverkeepers, July 17, 2008; photographs $B$ and $C$ taken by Kurt Carpenter, U.S. Geological Survey, July 9, 2008.)

\section{Background and Context}

Although the blue-green algae bloom in the lower Tualatin River was a highly unusual occurrence due to the presence of a surface scum, it was not unprecedented. The Tualatin River has a well-documented history of water-quality problems, including warm water temperatures, algal blooms, and periodic low-DO concentrations, the causes of which have been the subject of much research and water-quality model development over the past several decades (Carter and others, 1976; Oregon Department of Environmental Quality and Unified Sewerage Agency, 1982; Berger, 1993; Rounds and Doyle, 1997; Rounds and others, 1999; Risley, 2000; Rounds and Wood, 2001; Sullivan and Rounds, 2005; Bonn and Rounds, 2010).

Research and data have shown that algal populations in the Tualatin River are governed primarily by three factors: streamflow, sunlight available for photosynthesis, and phosphorus concentrations. When streamflow at Farmington (RM 33.3) decreases to less than about $300 \mathrm{ft}^{3} / \mathrm{s}$ in the low-flow summer season, sufficient time is available for phytoplankton to grow into a significant population (Rounds and others, 1999). Algae blooms in the lower Tualatin River typically occur in the reservoir reach of the river that begins at about RM 30, where the river widens and slows, providing ample time and light (lack of shading) during the summer lowflow period for algae to grow as they float downstream. In a typical summer, small populations of algae enter the reservoir reach from upstream, and substantial algal populations are not achieved until they have floated downstream as far as Elsner (RM 16.2) or farther. Prior to 2003, with sufficient time and light, an algal bloom was almost guaranteed in the reservoir reach of the lower river between Elsner (RM 16.2) and the Oswego Dam (RM 3.4). Phosphorus concentrations in the river then determined the maximum size of the resulting algal bloom, such that less phosphorus resulted in a smaller bloom. The bloom often would terminate when flows increased or sunlight levels decreased such that algal growth was no longer favored, or when phosphorus concentrations decreased enough to further limit phytoplankton growth (Carpenter and Rounds, 2013). Since 2003, however, this simple threeparameter model often has failed to explain the absence of even a moderate algal population in the Tualatin River, despite apparently favorable flow, light, and nutrient conditions.

Typically, moderate phytoplankton populations in the lower river would generate enough DO through photosynthesis to offset losses from sediment oxygen demand, resulting in DO levels that would be above the minimum DO criteria specified by the State of Oregon's water-quality standards. Lacking some minimum amount of photosynthesis from algal growth, however, DO concentrations in the river tend to decrease to levels below the minimum DO criteria toward the end of summer. 
Because the DO concentration in the Tualatin River is critical for aquatic life and is an important indicator of the river's health, it was imperative that a deeper understanding of the factors affecting phytoplankton populations be developed. To that end, as part of a recent USGS study (Carpenter and Rounds, 2013), the plankton community (phytoplankton and zooplankton) and water-quality conditions were characterized in the middle and lower reaches of the Tualatin River during the 2006-08 summer low-flow seasons. As part of that study, the various sources of streamflow including natural flow, WWTF effluent, and reservoir releases from Hagg Lake (primarily) and Barney Reservoir were estimated to assess how these might affect (1) the abundance and types of algae in the river, and (2) the bloom-crash sequences leading to the lowest DO concentrations. Given the greater frequency of low-DO events in recent years, data from 1991 to 2009 on longitudinal phytoplankton biomass (chlorophyll-a) and water-quality conditions (nutrients, turbidity, and flow) were analyzed.

One of the key findings of the study of Tualatin River algae was that declines in the phytoplankton population in the lower river were accompanied by a simultaneous decrease in chlorophyll- $a$ levels as far upstream as Rood Bridge at RM 38.4 (Carpenter and Rounds, 2013, fig. 7). The Rood Bridge site is well upstream of the reservoir reach where conditions are more favorable for algal growth. Conditions at Rood Bridge are more indicative of a "feedstock" of algae being transported into the reservoir reach. The analyses by Carpenter and Rounds (2013) suggested that an upstream algal inoculum was a key factor (in addition to flow, light, and phosphorus) in determining the eventual algal population (and DO concentrations) in the lower river. Although low levels of upstream inocula may contribute to low DO concentrations downstream and higher levels of such inocula can help maintain DO levels in the lower river, inputs of harmful blue-green algae such as those that occurred during June and July 2008 from the Wapato Lake area can have profound negative consequences for aquatic life, public recreation, and municipal water users.

\section{Data Sources, Methods, and Quality Assurance/Quality Control}

Water quality, streamflow, and (or) plankton data used in this study were collected by USGS, CWS, JWC, Jackson Bottom Wetlands Preserve, Bureau of Reclamation (Reclamation), Oregon Water Resources Department (OWRD), and the Oregon Department of Environmental Quality (ODEQ) (table 1). In addition to routine monitoring done by these groups, event-based targeted samples were collected during the early stages of the bloom by USGS and JWC to identify a possible source (inoculum) of the bloom and associated taste and odor issues. Sites along the Tualatin River where samples were collected or other data-collection activities occurred are listed in table 2 and shown in figures 4 and 5.

\section{Continuous Water-Quality and Streamflow Monitors}

The USGS operates a network of continuous waterquality monitors in the Tualatin River and its tributaries that collect hourly data (U.S. Geological Survey 2015a, 2015b). Three of the USGS water-quality monitors operating during the study period were in the Tualatin River near Scholls (RM 24.5), at Cook Park (RM 9.9), and at the Oswego Dam (RM 3.4). Several other USGS water-quality monitors were located on key tributaries including Scoggins, Gales, Dairy, Rock, Chicken, Beaverton, and Fanno Creeks. An additional continuous water-quality monitor in the Tualatin River at Highway 219 (RM 44.4) was operated by the Jackson Bottom Wetlands Preserve. The USGS operates streamgages in the Tualatin River at West Linn (RM 1.8) and Dilley (RM 58.8). OWRD operates streamgages in the Tualatin River at Farmington (RM 33.3), Rood Bridge (RM 38.4), and Old Hwy 47 (RM 62.3) among other locations. Flow data for Scoggins Creek downstream of Hagg Lake were obtained from Reclamation. Release rates from Barney Reservoir and Hagg Lake for flow augmentation were obtained from the Tualatin River Flow Management Technical Committee (Bonn, 2008).

\section{Plankton-Sample Collection, Processing, and Identification}

Phytoplankton and zooplankton assemblages were characterized using traditional quantitative methods and enumeration of preserved plankton samples. Tow-net samples of "net plankton, $80-\mu \mathrm{m}$ " also were collected at selected sites for microscopic observation of the unpreserved plankton community, starting May 18, 2008, and continuing through the summer season. Phytoplankton grab samples were collected from just below the river surface into $250-\mathrm{mL}$ polyethylene bottles and preserved with $2.5 \mathrm{~mL}$ of Lugol's solution (1 percent final concentration). Samples were shipped to Aquatic Analysts (Friday Harbor, Washington) for identification and enumeration. Permanent microscope slides were prepared for each sample by filtering an appropriate aliquot of the sample through a $0.45-\mu \mathrm{m}$ membrane filter (American Public Health Association, 1992). A section of filter was cut out and placed on a glass slide with immersion oil added to make the filter transparent. A cover slip was placed on top, with nail polish applied to the periphery for permanency. Most algae were identified by cross-referencing several taxonomic sources. A minimum of 100 algal units, defined as discrete particles (cells, colonies, or filaments), were counted along a measured transect on a microscope slide with a Zeiss standard microscope using $1,000 \times$ magnification. Only algae with intact chloroplasts that were believed to be alive at the time of collection were counted. Average biovolume estimates of each species were obtained from calculations of microscopic measurements of each alga taxon in each sample analyzed. The number of cells per colony or 


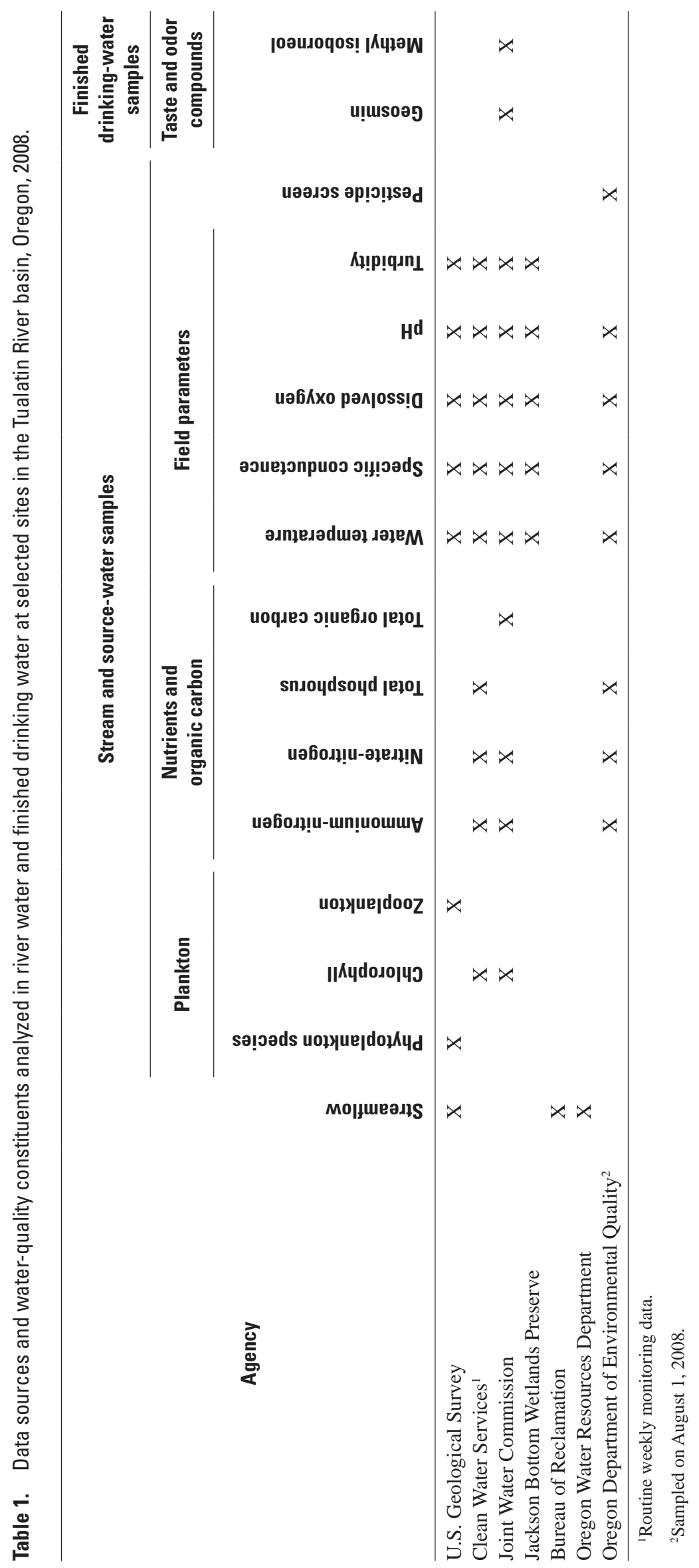


Table 2. Selected sampling sites and data collection activities in the Tualatin River basin, Oregon, $2006-08$.

[For a more complete listing of river mile indexes, refer to Carpenter and Rounds (2013). -, no data]

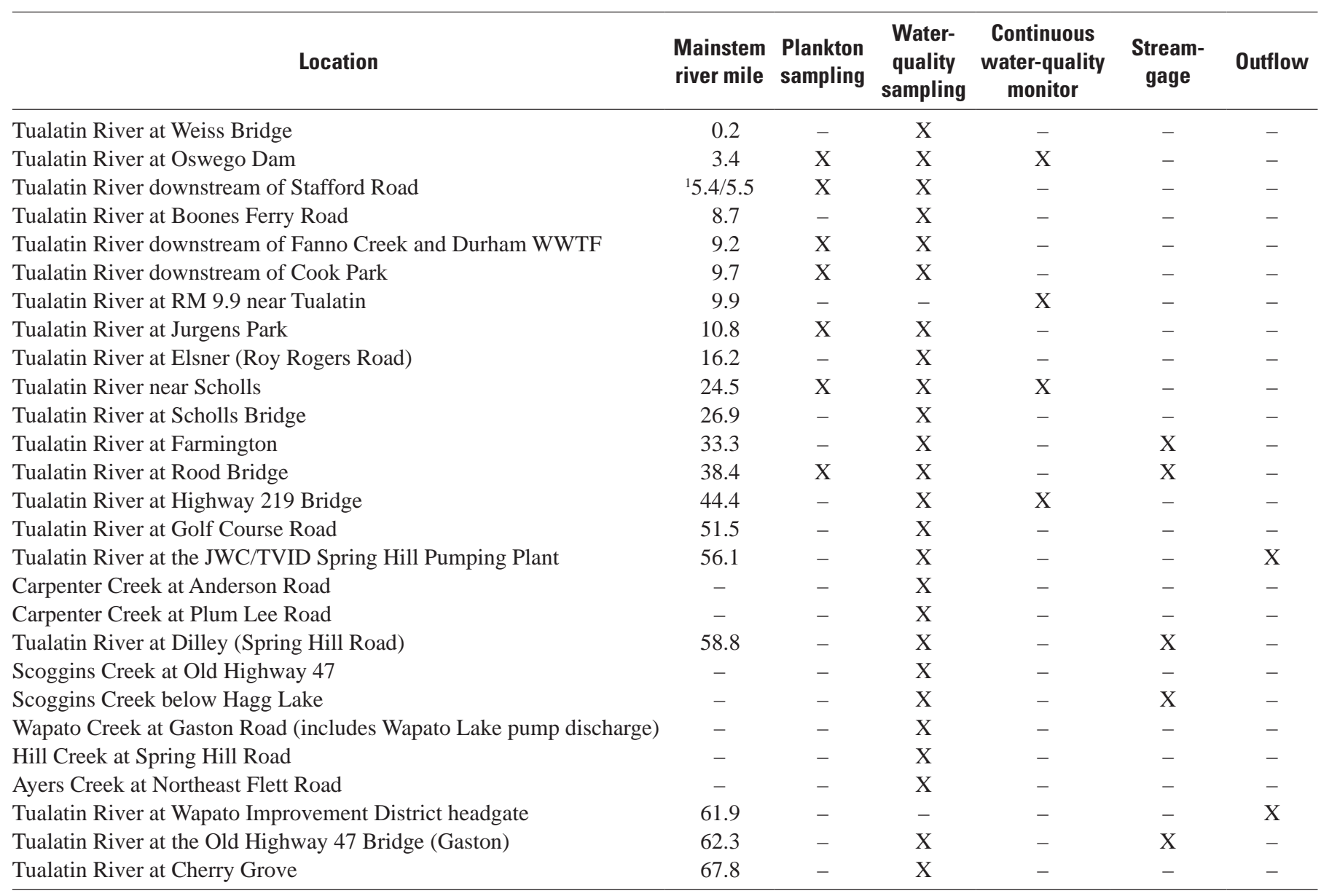

${ }^{1}$ U.S. Geological Survey plankton site is located 0.1 mile downstream of the bridge where Clean Water Services collects water samples.

the length of a filament was recorded to compute biovolume per algal-unit conversion factors to calculate total biovolume per taxon for each sample. The cell density, in number of cells per milliliter, was also determined for Anabaena only, when present.

\section{Zooplankton samples were collected with a}

12-in.-diameter, 80- $\mu \mathrm{m}$ mesh plankton net that was hand tossed from a canoe or from shore, capturing approximately $10 \mathrm{ft}$ of towing distance per sample for a total volume of approximately $222 \mathrm{~L}$ or $0.222 \mathrm{~m}^{3}$ per sample. The sample was washed down the net toward the "cod" end with repeated rinses into a 20-mL plastic vial and preserved with isopropyl alcohol (25 percent final concentration, by volume). Samples were shipped to ZP's Taxonomic Services (Lakewood, Washington) for identification and enumeration. Zooplankton densities, in number of organisms per cubic meter, were determined for each sample by counting a minimum of 400 organisms or, if fewer organisms were present, the entire sample.

\section{Microcystin Algal Toxin Analyses}

The USGS Oregon Water Science Center analyzed several samples for microcystin, a liver toxin sometimes produced by blue-green algae, using an enzyme-linked immunosorbent assay (ELISA) test kit from Abraxis (Fischer and others, 2001). Whole-water samples underwent three freeze-thaw cycles to lyse cells and liberate the toxins prior to analysis. Tests were run in duplicate, and averages of the two results were reported. Results of paired samples were typically within 5 percent (range: $0.1-10$ percent). The ELISA test kits used in this study have a detection limit of about $0.1 \mu \mathrm{g} / \mathrm{L}$, which is well within the range of usefulness for this study. 


\section{Clean Water Services Data}

Clean Water Services conducts routine water-quality monitoring at many locations within the Tualatin River basin, with weekly sample collection during summer at 13 or more sites in the Tualatin River between Cherry Grove (RM 67.8) and Weiss Bridge (RM 0.2). Grab-integratedcomposite samples were collected at five points across the river width, with each sample integrated over the depth of the river or as much as the top $10 \mathrm{ft}$, whichever was less. The five subsamples then were composited in a churn splitter. Water samples were processed and analyzed by the CWS Water-Quality Laboratory (Hillsboro, Oregon) using methods published in their watershed monitoring plan (Clean Water Services, 2006). Water samples for dissolved constituents were passed through 0.45 -micron syringe filters prior to analysis, and subsamples for chlorophyll- $a$ were collected onto glass fiber filters and analyzed fluorometrically (Clean Water Services, 2006).

All CWS data used in this study, including nutrients, chlorophyll- $a$, turbidity, and field parameters (water temperature, $\mathrm{pH}, \mathrm{DO}$, and specific conductance) were subjected to a comprehensive and rigorous quality assurance (QA) procedure by the CWS Water-Quality Laboratory. CWS Water-Quality Laboratory methods and protocols have been reviewed by the USGS Branch of Quality Systems and were determined to be suitable for use in this study. Field methods in use by CWS, including the collection of samples using depth- and width-integrating techniques and the use of churn splitters for subsampling, are consistent with USGS procedures and appropriate for the sites sampled. The CWS laboratory has been certified by the National Environmental Laboratory Accreditation Conference (NELAC), participates in a monthly-to-quarterly QA program with the USGS Oregon Water Science Center for nutrients and chlorophyll- $a$, and participates in many laboratory performance tests such as the twice-a-year USGS Standard Reference Sample (SRS) program, a national inter-laboratory comparison study (U.S. Geological Survey, 2013). SRS results from many years of participation in the program have shown that the CWS laboratory consistently produces high quality data that are sufficiently accurate for all the parameters used in this study.

\section{Joint Water Commission Data}

Prior to the water-quality problems of 2008, JWC staff monitored sites in the Tualatin River basin upstream of the JWC drinking-water treatment plant intake (RM 56.1) as part of a project designed to study disinfection by-product precursors. Staff collected total organic carbon (TOC) grab samples at several sites (fig. 5). Samples for TOC analysis were collected weekly beginning in October 2007 and were analyzed by Alexin Analytical Laboratory (Tigard, Oregon) using standard method 5310-C. Field measurements of water temperature, specific conductance, $\mathrm{pH}, \mathrm{DO}$, total chlorophyll, and turbidity were taken weekly using a Yellow Springs Instrument (YSI) 6920 multi-parameter sonde. Although the response of the chlorophyll sensor on that sonde was blank-checked against deionized water, those sensor data are not as definitive as laboratory results derived from water samples; regardless, the chlorophyll sensor data agreed well with available laboratory results from water samples. This monitoring continued until June 2008 when the cities of Hillsboro and Beaverton began receiving complaints of taste and odors in the treated water from JWC.

In response to changes in water quality at the drinkingwater treatment plant, JWC staff began collecting samples for taste and odor indicators (geosmin and methyl isoborneol [MIB]) in an attempt to identify the source of the issue. Samples also were collected periodically at points within the treatment plant and at locations in the distribution system to quantify the extent of the issue. Seven new stream sites were added to the monitoring program, with weekly or more frequent collection of field parameters. Sampling for taste and odor indicators continued every 2-12 days until early September 2008. Geosmin and MIB samples collected prior to July 2008 were analyzed by MWH Laboratories (Monrovia, California) by solid-phase micro-extraction (SPME). Geosmin and MIB samples collected after July 1, 2008 were analyzed by CH2M-Hill (Corvallis, Oregon) using SPME according to standard method 6040D (American Public Health Association, 1992).

\section{Oregon Department of Environmental Quality Data}

Oregon Department of Environmental Quality staff conducted an investigation in response to a report of a fish kill near the Wapato Lake pump house during the latter part of the bloom period in 2008. Water-quality samples were collected and field measurements were taken on August 1, 2008. The specific parameters and constituents analyzed are listed in table 1. The ODEQ Water-Quality Laboratory also has rigorous internal QA procedures and participates in the USGS SRS inter-laboratory comparison program; results have shown that the data produced by the ODEQ laboratory are sufficiently accurate for the parameters used in this study. 


\section{Bloom Origination, Discovery, and Tracking to Wapato Lake}

\section{Early Bloom Indications, June 2008}

The first indications of unusual water quality in the Tualatin River during summer 2008 were provided by JWC customers in Hillsboro and Beaverton who reported complaints of "earthy" and "musty" tasting drinking water on June 3. A reconstructed timeline of events is shown in table 3. Over the next week, hundreds of customer complaint calls were received by JWC, and the local media published several stories on the drinking-water issue. JWC attempted to remedy the issue with various operational and distribution methods, but without success. Suspecting certain taste-andodor compounds in the raw source water, JWC staff began to look for potential sources during their routine streammonitoring activities. On June 11, JWC staff were alerted that Wapato Lake was still full of water; normally it would have been pumped out and growing crops by June. Also on June 11, floating algal mats were observed in the internal Wapato Lake canal that routes lake water to the pump house (fig. 8).

Table 3. Reconstructed timeline of events associated with the bloom of Anabaena flos-aquae in Wapato Lake and downstream in the Tualatin River, Oregon, 2008.

[A bbreviations: RM, river mile; JWC, Joint Water Commission; WTP, Water Treatment Plant; USGS, U.S. Geological Survey; CWS, Clean Water Services; TRK, Tualatin Riverkeepers]

\begin{tabular}{|c|c|}
\hline Date & Description \\
\hline December 2-3, 2007 & Winter storm causes levee to fail \\
\hline Late May/early June & $\begin{array}{l}\text { River levels recede enough to allow pumping without repairing the levee; unclear whether levee was patched } \\
\text { temporarily }\end{array}$ \\
\hline June 1 & Wapato Lake pump discharge or lake drainage begins intermittently \\
\hline June 3 & First reports of taste-and-odor issues by drinking water customers \\
\hline June 9 & Wapato Lake pump discharge stops or lake drainage decreases temporarily; downstream water quality improves slightly \\
\hline June 12 & Treatment with powdered activated carbon begins at JWC WTP \\
\hline June 13 & Taste-and-odor indicators confirmed present at JWC WTP \\
\hline June 19 & JWC staff observes that Wapato Lake pumps are operating \\
\hline June 30 & $\begin{array}{l}\text { Wapato Lake pumping increases; abundant sunshine prevails; Anabaena found at all sites sampled from Rood Bridge } \\
\text { (RM 38.4) to Oswego Dam (RM 3.4) }\end{array}$ \\
\hline July 10 & $\begin{array}{l}\text { Bloom arrives at Oswego Dam (RM 3.4) according to USGS dissolved oxygen data; CWS increases reservoir releases } \\
\text { to alleviate water-quality issues }\end{array}$ \\
\hline July 12 & Oregon Department of Human Services issues public health advisory \\
\hline July 16 & Anabaena streaks still present, Elsner (RM 16.2) to Cook Park (RM 9.9) (USGS observations) \\
\hline July 17 & Some algal mats still present, Cook Park (RM 9.9) to Oswego Dam (RM 3.4) (TRK observations) \\
\hline July 19 & $\begin{array}{l}\text { Confirmation of high levels of chlorophyll, plankton, phosphorus, organic nitrogen, and oxygen demands in Wapato } \\
\text { Lake discharges }\end{array}$ \\
\hline July 23 & Wapato Lake pumping still at full capacity in effort to pump the lake dry by August 1 \\
\hline July 25 & Oregon Department of Human Services lifts public health advisory \\
\hline July 30 & Wapato pumping decreases based on flow balance estimates \\
\hline
\end{tabular}


No definitive records exist to document when the Wapato pumps were operating in summer 2008, but nearby streamgage data were used to estimate the timing and magnitude of the Wapato Lake discharges. Wapato Creek joins the Tualatin River between the Old Highway 47 (Gaston, RM 62.3) and Dilley (RM 58.8) streamgages. By subtracting the sum of measured streamflows in Scoggins Creek below Henry Hagg Lake (Reclamation station 14202980) and in the Tualatin River at Old Highway 47 (OWRD station 14202510) from the measured streamflow in the Tualatin River at Dilley (USGS station 14203500), a rough estimate of the discharge from the Wapato Creek drainage was obtained. TVID did not make any diversions from the Tualatin River into the Wapato canals in 2008. Some diversions from Scoggins Creek or the Tualatin River would tend to bias these flow estimates for Wapato Creek, but such diversions were likely to be small, on the order of less than $2 \mathrm{ft}^{3} / \mathrm{s}$. The estimated discharge from Wapato Creek in early June was about $13 \mathrm{ft}^{3} / \mathrm{s}$ (fig. 11). The Wapato pump house has two pumps, one "large" and one "small," with a combined nominal pumping rate of $13,000 \mathrm{gal} / \mathrm{min}$ (about $29 \mathrm{ft}^{3} / \mathrm{s}$ ). It is not clear whether pumping was occurring in early June, or whether lake water was draining out of the unrepaired levee breach. The date of any initial repair work on the levee was not documented, but a partial repair may have occurred prior to June 19 when at least one of the pumps was observed to be operating by JWC staff. Any pumping or drainage was likely intermittent at the beginning of June, given the variation in the Wapato Creek discharge estimates, but these calculations confirm that water was being discharged from Wapato Lake in early June when the first taste-and-odor issues were reported.

JWC staff identified odor issues at the WTP on June 12, and treatment additions of powdered activated carbon were initiated. Water samples collected by JWC staff on June 13 confirmed the presence of geosmin at concentrations of 16 and 13 nanograms per liter (ng/L), or parts-per-trillion, in samples of raw and finished (treated) drinking water, respectively (table 4). Geosmin can be detected by humans at concentrations as low as 5-10 ng/L (Gottler and others, 2007).



Figure 11. Estimated discharge from the Wapato Creek drainage (and Wapato Lake), as estimated from a mass balance of measured streamflows in Scoggins Creek and the Tualatin River, Oregon, June-July 2008. 


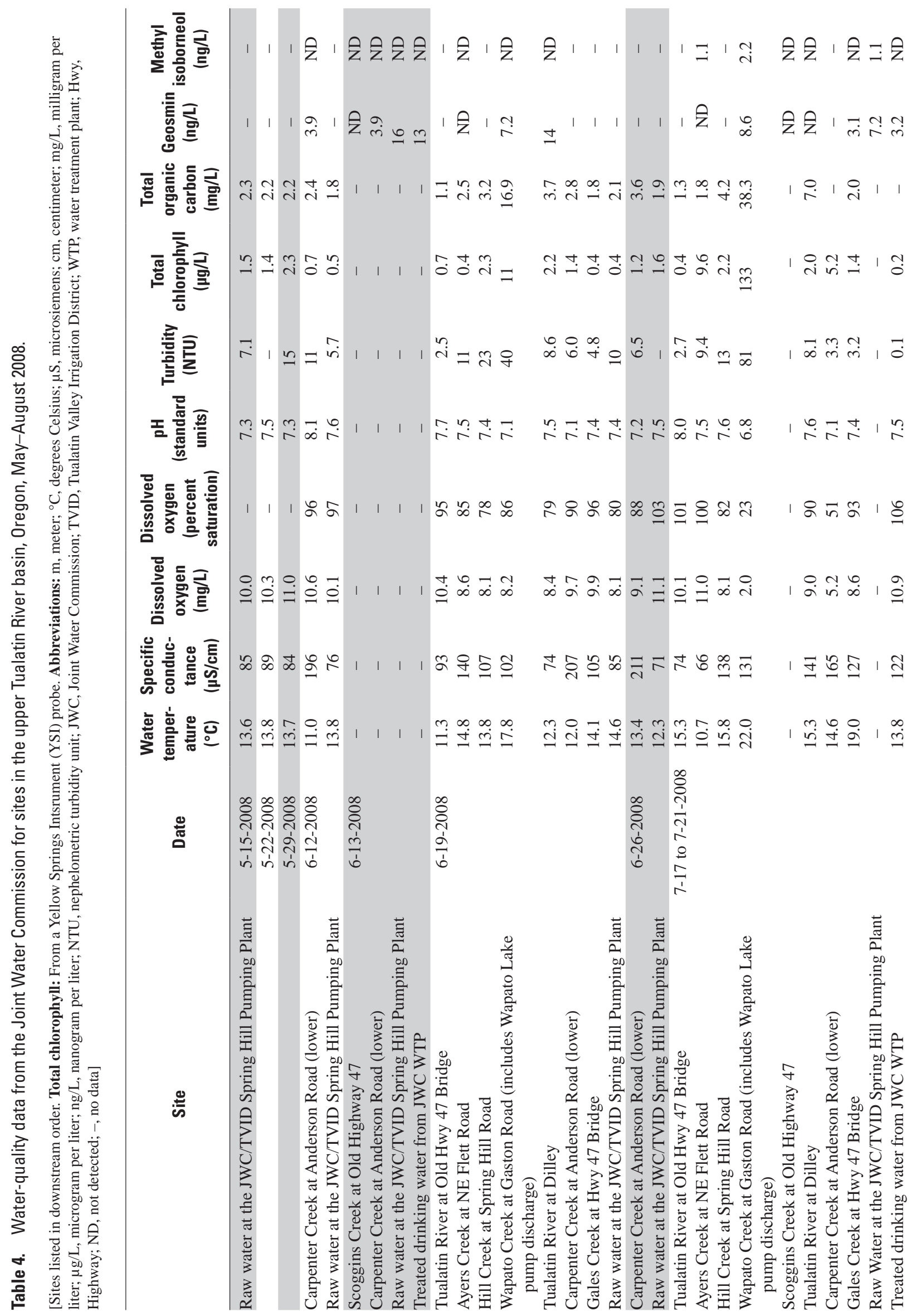









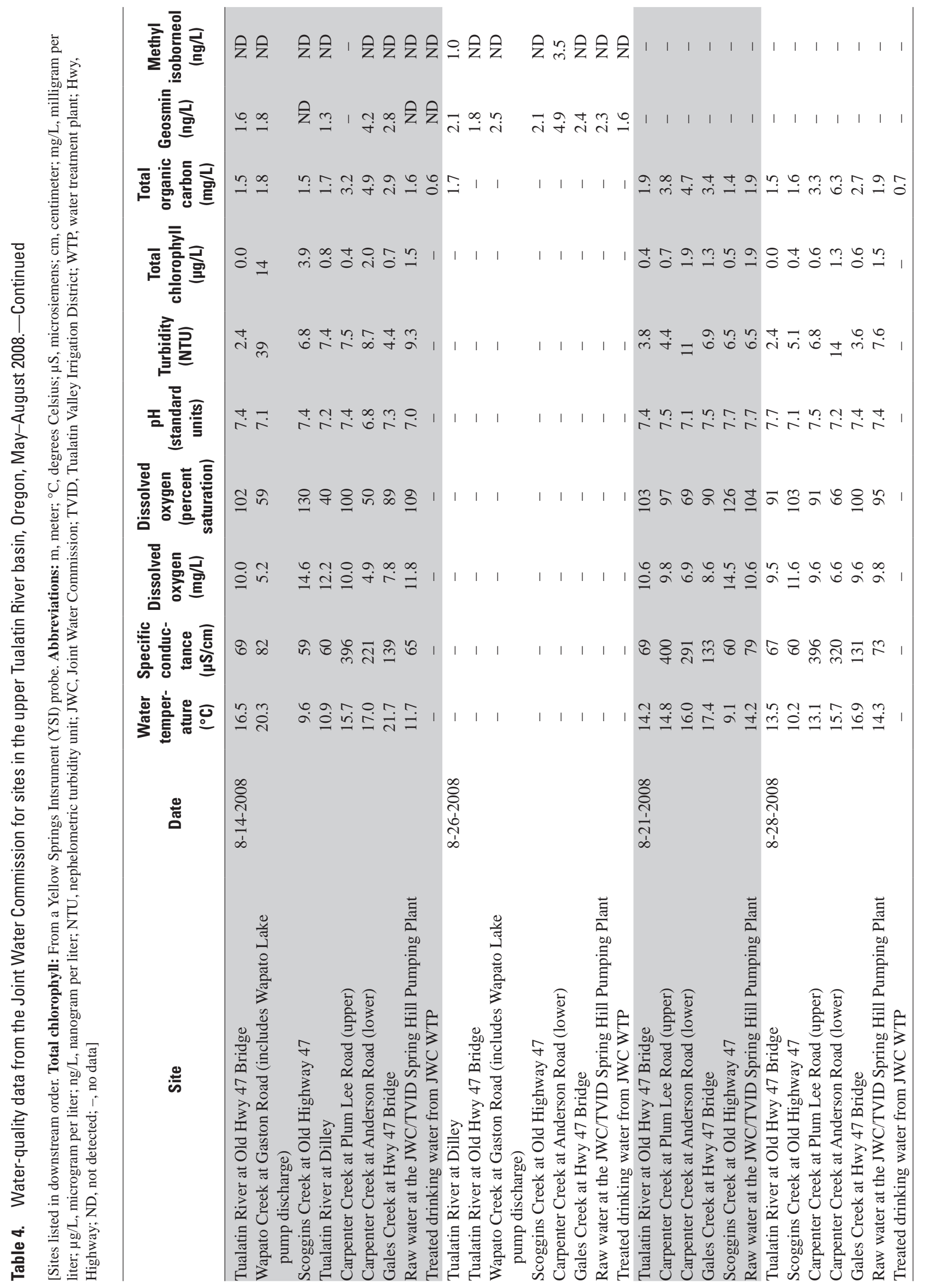


Samples collected June 19 from Wapato Creek at Gaston Road, directly downstream of the Wapato pump house (fig. 5), revealed elevated concentrations of geosmin, total chlorophyll, turbidity, and TOC compared to other samples collected that day. Downstream in the Tualatin River at Dilley (RM 58.8), the concentration of geosmin was two times higher (14 ng/L) than at the Wapato pump house (table 4). Concentrations of geosmin in Wapato Creek may have varied substantially as a function of pumping rate and river level, and concentrations at the Dilley site also could have been affected by other sources, including some tributary ponds that were not sampled. Although the highest overall geosmin concentrations tended to occur in the Wapato Lake discharge and sites downstream affected by that discharge, geosmin also was detected in Carpenter and Gales Creeks, although at lower concentrations. Another taste-and-odor compound, MIB, was detected only a few times and at concentrations less than the human detection threshold level of $29 \mathrm{ng} / \mathrm{L}$ (Izaguirre and others, 1982) (table 4).

The source of the Anabaena cells that produced the bloom in Wapato Lake is unclear. Anabaena produces copious quantities of resting spores (akinetes) during blooms, which deposit in sediments. The bloom could have originated from akinetes previously deposited in the lakebed sediments or the adjacent hydrologic system. Although most of the lakebed dries out and is farmed in summer, the internal canals of the lake stay wet and would remain as viable habitat for the akinetes. Another possibility is that viable cells could have been transferred to the lake from the Tualatin River through the levee breach or from upstream ponds in the Wapato Lake drainage basin (fig. 5).

Chlorophyll-a samples for laboratory analysis were not routinely collected from sites upstream of the Highway 219 bridge (RM 44.4) in 2008 (table 5), and JWC monitoring of total chlorophyll with a field probe was not performed at sites in and around the Wapato Lake area until June 19 when total chlorophyll levels in Wapato Lake pump discharges were elevated (11 $\mu \mathrm{g} / \mathrm{L}$, table 4).

Clouds and rain during the first week of June (about 0.8 in. of rain, mostly on June 3) temporarily slowed algal photosynthesis in Wapato Lake and downstream in the Tualatin River (data available from U.S. Geological Survey, 2010). Pumping/drainage from Wapato Lake then appeared to stop for a couple weeks in mid-June (fig. 11), which may have contributed to a slight improvement in water quality-lower total phosphorus concentrations - in the Tualatin River at Dilley (RM 58.8), downstream of the Wapato Creek inflow (table 5).

The early June pumping or drainage from Wapato Lake was one potential source of Anabaena to the Tualatin River, although drainage from other water bodies, nursery ponds, canals, wetlands, or pooled backwaters also may have contributed. Many of the small Tualatin River tributaries between Gaston and Scholls include small instream ponds. On June 11, 1 week after the taste and odor issues were first reported, colonies of Anabaena and another colonial blue-green algae (Aphanizomenon) were noted in net plankton samples from the Tualatin River at Rood Bridge (RM 38.4), Jurgens Park (RM 10.8), and Oswego Dam (RM 3.4). Enumeration (cell counts) of samples collected on June 17 showed 573 Anabaena cells per milliliter in the Tualatin River near Scholls (RM 24.5), with similar levels (474 cells per $\mathrm{mL}$ ) downstream of Fanno Creek (RM 9.2), but no Anabaena colonies detected at Jurgens Park (RM 10.8) (table 6). This suggests that the inoculum for the bloom may have been released to the river intermittently, supporting the conclusions of the flow data analysis and estimated discharges from Wapato Lake (fig. 11). Downstream variations in Anabaena abundance also could be due to variability in the success of Anabaena to survive and reproduce in the Tualatin River (from variations in sunlight, for example), from uneven discharge of algae from Wapato Lake during draining (possible wind effects that push floating mats toward or away from the pumps or the levee breach), and possibly also from zooplankton grazing.

\section{Mature Bloom, July 2008}

The algal bloom in the Tualatin River grew considerably during the first week of July, when weather and flow conditions were favorable for algal growth. On July 4-5, the DO concentration measured by a USGS water-quality monitor at RM 24.5 increased anomalously, above historical conditions for that time of year, and indicative of a substantial amount of photosynthetic DO production. On July 7, about 1 week after the Wapato Lake pumping appeared to increase (fig. 11), a CWS sampling crew observed floating mats of algae in the Tualatin River at Elsner (RM 16.2), well within the reservoirlike reach of the river that is prone to algal growth. Two days later, a surface scum was observed in the Tualatin River by USGS staff and members of the Tualatin Riverkeepers group at Jurgens Park (RM 10.8), and by USGS staff downstream of Stafford Road (RM 5.4). The bloom reached the Oswego Dam (RM 3.4) water-quality monitoring site on July 10. A reconstructed timeline of events is shown in table 3 .

Water samples from July 9 were examined microscopically and results showed that the bloom was dominated by Anabaena, a colonial blue-green algae that often forms blooms and surface scums in nutrient-enriched rivers, lakes, and reservoirs (Wehr and Sheath, 2003). Algae samples were sent to Aquatic Analysts for rush analysis, who confirmed the initial identification as Anabaena flos-aquae. Routine and targeted plankton sampling by USGS starting July 9 revealed elevated levels of Anabaena at many sites in the lower Tualatin River (table 6). Selected samples were analyzed by USGS for the algal toxin microcystin, and results confirmed the presence of the toxin at levels below the Oregon recreational health-hazard guideline in effect at that time (8 $\mu \mathrm{g} / \mathrm{L})$, but one sample exceeded the World Health Organization drinking-water guideline of $1 \mu \mathrm{g} / \mathrm{L}$ (table 6). The U.S. Environmental Protection Agency (EPA) did not have a drinking-water standard for microcystins in 2008. 


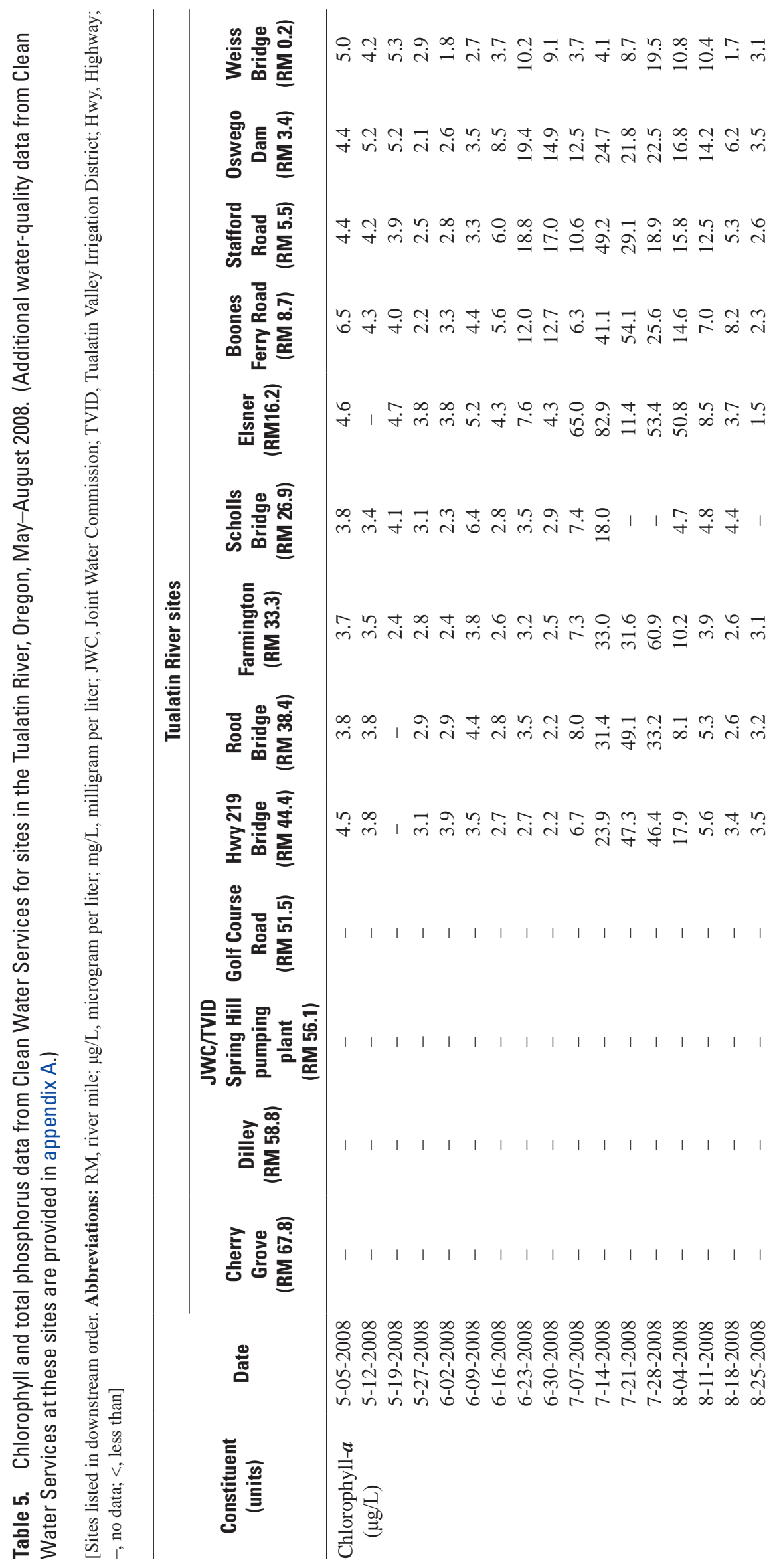







Table 6. Anabaena flos-aquae cell counts and microcystin algal toxin concentrations for select sites in the Tualatin River basin, Oregon, June-August 2008.

[Anabaena flos-aquae abundance: Oregon Department of Human Service's public health action level in 2008 was 100,000 cells per mL. M icrocystins: Samples were analyzed for five microcystin algal toxins (MC-LR, MC-RR, MC-YR, MC-LW, MC-LF) using an Abraxis enzyme-linked immunosorbent assay (ELISA) (see Data Sources, Methods, and Quality Assurance/Quality Control section). A bbreviations: JWC, Joint Water Commission; TVID, Tualatin Valley Irrigation District; mL, milliliter; $\mu \mathrm{g} / \mathrm{L}$, microgram per liter; <, less than laboratory detection limit of $0.1 \mu \mathrm{g} / \mathrm{L}$; ND, not detected; -, no data]

\begin{tabular}{|c|c|c|c|c|}
\hline $\begin{array}{c}\text { Sample } \\
\text { date }\end{array}$ & Site & $\begin{array}{l}\text { River } \\
\text { mile }\end{array}$ & $\begin{array}{l}\text { Anabaena flos- } \\
\text { aquae abundance } \\
\text { (cells per mL) }\end{array}$ & $\begin{array}{c}\text { Microcystins } \\
\text { ( } \mu \mathrm{g} / \mathrm{L})\end{array}$ \\
\hline $5-19-2008$ & Tualatin River at Rood Bridge & 38.4 & ND & - \\
\hline 5-19-2008 & Tualatin River at Jurgens Park & 10.8 & ND & - \\
\hline $6-11-2008$ & Tualatin River at Rood Bridge & 38.4 & 781 & - \\
\hline $6-11-2008$ & Tualatin River at Jurgens Park & 10.8 & ND & - \\
\hline $6-17-2008$ & Tualatin River near Scholls & 24.5 & 573 & - \\
\hline $6-17-2008$ & Tualatin River at Jurgens Park & 10.8 & ND & - \\
\hline $6-17-2008$ & Tualatin River downstream of Cook Park & 9.7 & ND & - \\
\hline $6-17-2008$ & Tualatin River downstream of Fanno Creek & 9.2 & 474 & - \\
\hline $6-17-2008$ & Tualatin River at Stafford & 5.4 & ND & - \\
\hline $6-17-2008$ & Tualatin River at Oswego Dam & 3.4 & ND & - \\
\hline $6-30-2008$ & Tualatin River at Rood Bridge & 38.4 & ND & - \\
\hline $6-30-2008$ & Tualatin River at Jurgens Park & 10.8 & ND & - \\
\hline 7-01-2008 & Tualatin River near Scholls & 24.5 & 90 & - \\
\hline 7-01-2008 & Tualatin River at Jurgens Park & 10.8 & ND & - \\
\hline 7-01-2008 & Tualatin River downstream of Cook Park & 9.7 & ND & - \\
\hline 7-01-2008 & Tualatin River downstream of Fanno Creek & 9.2 & 1,212 & - \\
\hline 7-01-2008 & Tualatin River at Stafford & 5.4 & ND & - \\
\hline 7-01-2008 & Tualatin River at Oswego Dam & 3.4 & ND & - \\
\hline 7-09-2008 & Tualatin River near Scholls & 24.5 & 884 & - \\
\hline 7-09-2008 & Tualatin River at Jurgens Park & 10.8 & 23,300 & 2.4 \\
\hline 7-09-2008 & Tualatin River downstream of Cook Park & 9.7 & 29,858 & 0.19 \\
\hline 7-09-2008 & Tualatin River downstream of Fanno Creek & 9.2 & 20,958 & - \\
\hline 7-09-2008 & Tualatin River at Stafford & 5.4 & 11,505 & 0.14 \\
\hline 7-09-2008 & Tualatin River at Oswego Dam & 3.4 & ND & - \\
\hline $7-15-2008$ & Tualatin River at Rood Bridge & 38.4 & 11,726 & - \\
\hline 7-15-2008 & Tualatin River at Jurgens Park & 10.8 & 16,734 & - \\
\hline $7-16-2008$ & Tualatin River near Scholls & 24.5 & 6,107 & - \\
\hline 7-16-2008 & Tualatin River at RM 23.2 & 23.2 & 11,036 & - \\
\hline 7-16-2008 & Tualatin River at RM 21.1 & 21.1 & 14,831 & - \\
\hline 7-16-2008 & Tualatin River at RM 20.4 & 20.4 & 3,499 & - \\
\hline $7-16-2008$ & Tualatin River at RM 17.9 & 17.9 & 12,638 & - \\
\hline $7-16-2008$ & Tualatin River at RM 17.3 & 17.3 & 33,203 & - \\
\hline 7-16-2008 & Tualatin River at RM 13.5 & 13.5 & 10,677 & - \\
\hline 7-16-2008 & Tualatin River at Jurgens Park & 10.8 & 33,825 & $<0.1$ \\
\hline $7-19-2008$ & Wapato Lake pump discharge & 60.5 & 5,568 & - \\
\hline $7-21-2008$ & Wapato Lake pump discharge & 60.5 & 3,007 & - \\
\hline 7-21-2008 & Tualatin River at JWC/TVID Spring Hill Pumping Plant & 56.1 & 1,342 & - \\
\hline $8-05-2008$ & Tualatin River at Jurgens Park & 10.8 & ND & - \\
\hline 8-06-2008 & Tualatin River near Scholls & 24.5 & ND & - \\
\hline 8-06-2008 & Tualatin River downstream of Cook Park & 9.7 & ND & - \\
\hline 8-06-2008 & Tualatin River downstream of Fanno Creek & 9.2 & ND & - \\
\hline 8-06-2008 & Tualatin River at Stafford & 5.4 & ND & - \\
\hline 8-06-2008 & Tualatin River at Oswego Dam & 3.4 & ND & - \\
\hline
\end{tabular}


Meanwhile, TOC concentrations in the upper Tualatin River at the Spring Hill pumping plant (JWC's drinking water intake) increased markedly in early July to 5-6 mg/L (fig. 12). Detectable levels of taste-and-odor compounds continued to be present in Wapato Creek and in the raw and finished drinking water at the JWC WTP through August (table 4). Enhanced drinking-water treatment with powdered activated carbon continued.

Water samples collected by USGS from Wapato Creek at Gaston Road on July 19 confirmed that Wapato Lake discharges had high concentrations of organic nitrogen and chlorophyll-a (330 $\mu \mathrm{g} / \mathrm{L})$, along with substantial concentrations of phosphorus and suspended sediment, and high oxygen demand (table 7). That sample and additional water samples collected by JWC on July 21 from Wapato
Creek at Gaston Road and from the Tualatin River at the Spring Hill pumping plant revealed elevated levels of algae and zooplankton, including a moderate abundance of Anabaena flos-aquae (tables 8 and 9, appendix B). The relative abundance and species composition of algae in those samples, especially the dominance of Trachelomonas volvocina and Cryptomonas erosa, strongly suggested that Wapato Lake discharges were indeed the source of the algal material in samples from the Spring Hill pumping plant. Although Anabaena flos-aquae comprised less than 3 percent of the total algal biovolume in the Wapato Lake discharge on those dates, conditions for the growth of this blue-green species became more favorable and the bloom increased as it moved downstream, with Anabaena becoming more prevalent in the lower river (fig. 13).

Table 7. Results of water-quality tests on samples of Wapato Lake pump discharge compared with nearby locations, upper Tualatin River basin, July 19 and 21, 2008.

[Sites listed in downstream order. Parameter: $\mathrm{BOD}_{5}$, 5-day biochemical oxygen demand; $\mathrm{CBOD}_{5}$, 5-day carbonaceous biochemical oxygen demand; COD, chemical oxygen demand; TSS, total suspended solids. Units: $\mathrm{ft}^{3} / \mathrm{s}$, cubic foot per second; $\mathrm{kg} / \mathrm{d}$, kilogram per day; $\mu \mathrm{g} / \mathrm{L}, \mathrm{microgram}$ per liter; $\mathrm{mg} / \mathrm{L}, \mathrm{milligram}$ per liter; mL, milliliter. RM, river mile; -, no data; , approximately]

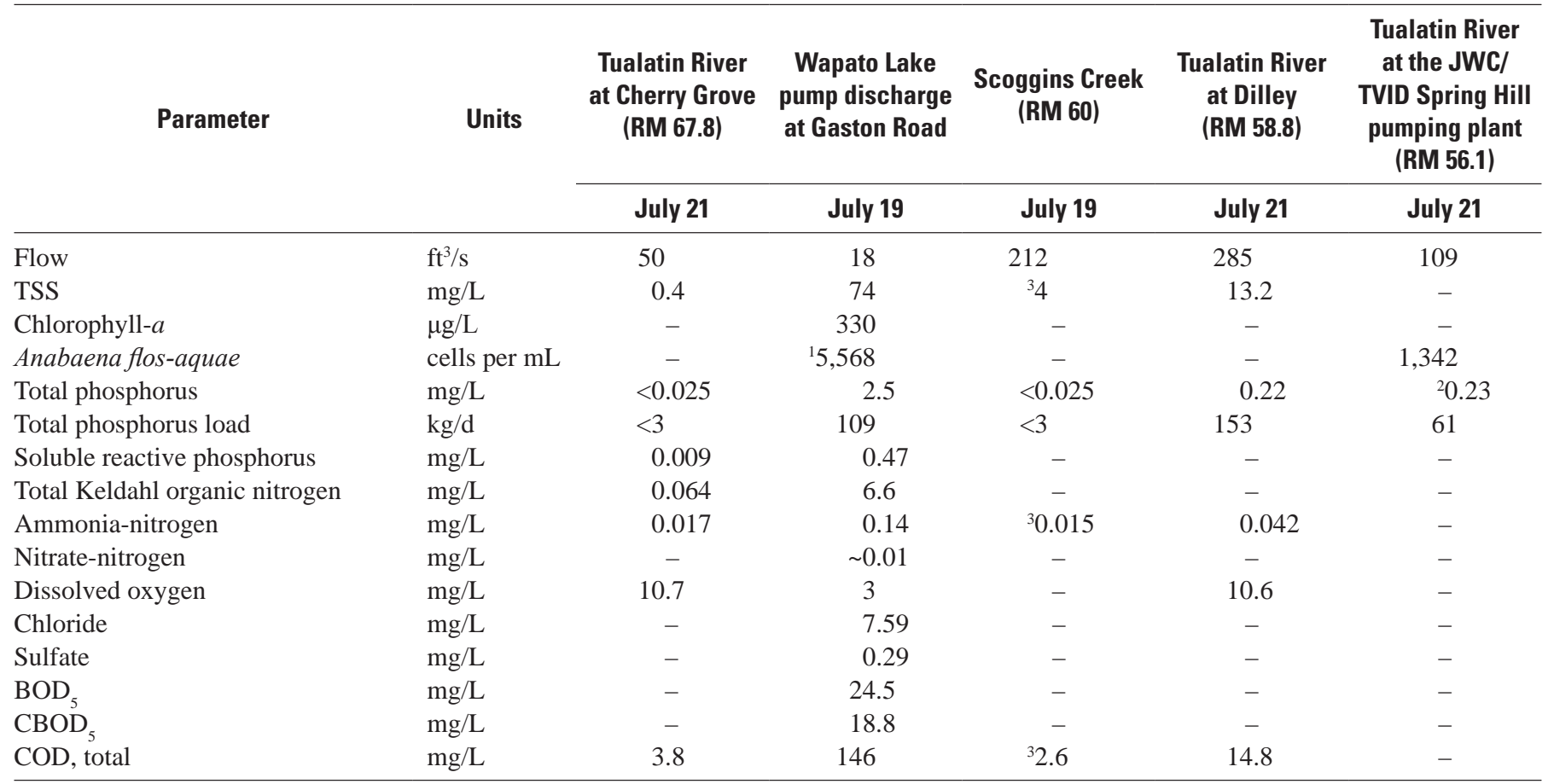

\footnotetext{
${ }^{1}$ The Anabaena density was 3,007 cells per mL on July 21.
}

${ }^{2}$ Average of two measurements on July 16 and July 23.

${ }^{3}$ Data from July 22. 
Table 8. Ten most abundant algal taxa in Wapato Lake pump discharge and abundances downstream in the Tualatin River at the JWC/TVID Spring Hill pumping plant, Oregon, July 19 and 21, 2008.

[For a full listing of species abundances, see appendix B. A bbreviations: $\mu \mathrm{m}^{3} / \mathrm{mL}$, cubic micron per milliliter; JWC, Joint Water Commission; TVID, Tualatin Valley Irrigation District; RM, river mile]

\begin{tabular}{|c|c|c|c|c|}
\hline \multirow{3}{*}{ Scientific name } & \multirow{3}{*}{ Algal group } & \multicolumn{2}{|c|}{$\begin{array}{l}\text { Wapato Lake } \\
\text { pump discharge }\end{array}$} & \multirow{2}{*}{$\begin{array}{c}\begin{array}{c}\text { Spring Hill } \\
\text { pumping plant } \\
\text { (RM 56.1) }\end{array} \\
\text { July } 21\end{array}$} \\
\hline & & July 19 & July 21 & \\
\hline & & \multicolumn{3}{|c|}{ Taxon biovolume $\left(\mu \mathrm{m}^{3} / \mathrm{mL}\right)$} \\
\hline Trachelomonas volvocina & Euglenoid & $3,673,423$ & $7,934,593$ & 404,826 \\
\hline Cryptomonas erosa & Cryptophyte & $3,619,136$ & $5,003,093$ & 418,786 \\
\hline Unidentified flagellate & Unknown & $1,876,383$ & $1,671,707$ & 5,369 \\
\hline Trachelomonas hispida & Euglenoid & 584,630 & 631,400 & 56,375 \\
\hline Chlamydomonas sp. & Green algae & 651,444 & 488,583 & 52,348 \\
\hline Scenedesmus quadricauda & Green algae & 537,442 & 234,520 & 65,784 \\
\hline Anabaena flos-aquae & Blue-green algae & 373,049 & 201,447 & 89,932 \\
\hline Marssoniella elegans & Unknown & 0 & 541,200 & 96,643 \\
\hline Actinastrum hantzschii & Green algae & 534,519 & 0 & 0 \\
\hline Nitzschia capitellata & Diatom & 0 & 324,720 & 38,657 \\
\hline
\end{tabular}

Table 9. Zooplankton taxa in water samples collected from Wapato Lake pump discharge and downstream in the Tualatin River at the JWC/TVID Spring Hill pumping plant, Oregon, July 19 and 21, 2008.

[Values are density, in number per cubic meter. A bbreviations: JWC, Joint Water Commission; TVID, Tualatin Valley Irrigation District; RM, river mile; sp., species]

\begin{tabular}{|c|c|c|c|c|}
\hline \multirow[t]{2}{*}{ Zooplankton taxa } & \multirow[t]{2}{*}{ Group } & \multicolumn{2}{|c|}{$\begin{array}{c}\text { Wapato Lake } \\
\text { pump discharge } \\
\text { (near Tualatin River at RM 60.1) }\end{array}$} & \multirow{2}{*}{$\begin{array}{c}\begin{array}{c}\text { Tualatin River at the } \\
\text { JWC/TVID Spring Hill } \\
\text { pumping plant (RM 56.1) } \\
\text { July } 21\end{array} \\
\end{array}$} \\
\hline & & July 19 & July 21 & \\
\hline Cyclopoid copepodites & Copepod & 384,507 & 415,790 & 6,780 \\
\hline Diacyclops thomasi & Copepod & 209,859 & 345,614 & 6,780 \\
\hline Copepod nauplii & Copepod & 63,380 & 8,772 & 0 \\
\hline Daphnia pulicaria & Cladoceran & 9,859 & 14,035 & 0 \\
\hline Difflugia sp. & Other zooplankton & 8,451 & 10,526 & 1,695 \\
\hline Diaptomus reighardi & Copepod & 9,859 & 0 & 0 \\
\hline Bosmina longirostris & Cladoceran & 4,225 & 3,509 & 0 \\
\hline Conochilus unicornis & Rotifer & 0 & 5,263 & 1,695 \\
\hline Daphnia mendotae & Cladoceran & 5,634 & 0 & 0 \\
\hline Oligochaete sp. & Other zooplankton & 2,817 & 0 & 0 \\
\hline Brachionus angularis & Rotifer & 0 & 1,754 & 0 \\
\hline Chydorus sphaericus & Cladoceran & 1,409 & 0 & 0 \\
\hline Keratella irregularis & Rotifer & 1,409 & 0 & 0 \\
\hline
\end{tabular}




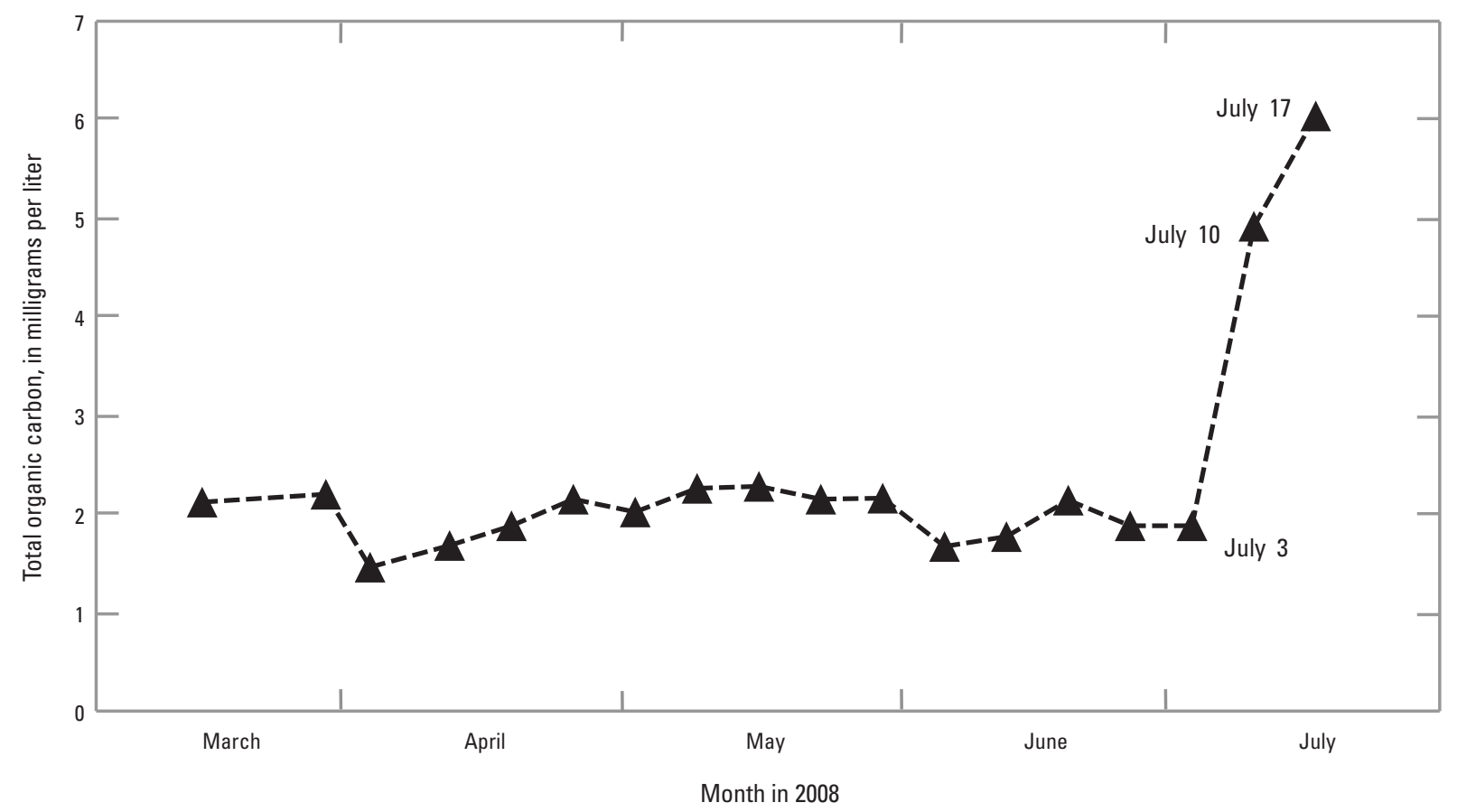

Figure 12. Total organic carbon concentrations in the Tualatin River at the Spring Hill pumping plant (river mile 56.1), Oregon, March-July 2008.



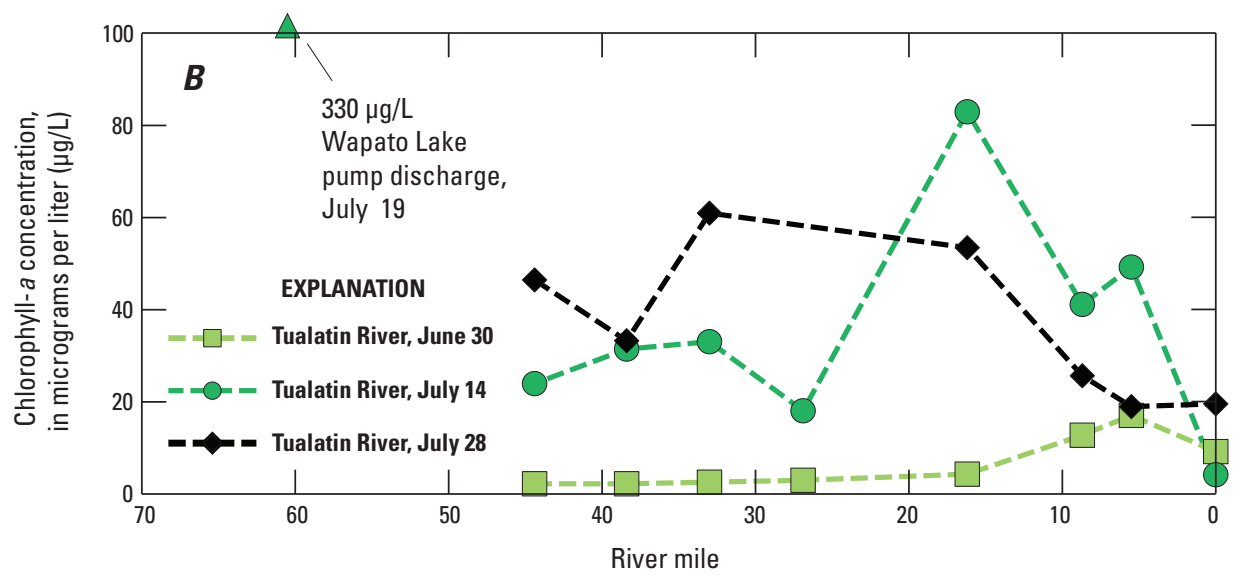

Figure 13. Longitudinal pattern in Anabaena flos-aquae abundance (A) and chlorophyll-a concentrations $(B)$ in the Tualatin River along with measurements from the Wapato Lake pump discharge, Oregon, July 2008. (A) Samples were collected during a 7-day period (July 15-21), and travel times vary between sites; therefore, values are not necessarily comparable between sites, but the general pattern is valid (see table 6 for specific data points). ( $B$ ) Data are from Clean Water Services (see table 5). 


\section{Analysis and Confirmation of Bloom Source}

Preliminary evidence pointed to Wapato Lake discharges as a potential source of downstream changes in water quality and the algal community. To confirm that Wapato Lake pump discharges were indeed the cause of the Anabaena bloom in the lower Tualatin River, and to determine how the river responded to this inoculation of plankton and nutrients, waterquality data from continuous monitors located at Highway 219 (RM 44.4), near Scholls (RM 24.5), at Cook Park (RM 9.9), and at Oswego Dam (RM 3.4) were analyzed, accounting for the travel time between those locations. Specific increases in the measured DO concentration can be used as tracers for algal photosynthesis and an indication of when the bloom reached each location.

The RM 24.5 DO data indicate that a large population of algae moved past that site on July 4-5 (figs. 14 and 15). The estimated travel time from Wapato Lake to RM 24.5 is approximately 4-5 days (Carpenter and Rounds, 2013, table 3), assuming a water velocity of $0.3-0.4 \mathrm{mi} / \mathrm{hr}$ for the approximate $250 \mathrm{ft}^{3} / \mathrm{s}$ of streamflow in the Tualatin River at Dilley at the time (fig. 11). For Wapato Lake discharges to have been associated with the bloom at RM 24.5 on July 4, the travel-time information suggests that pumping from Wapato Lake must have increased on or about June 30. The Wapato Creek discharge estimates confirm that pumping from Wapato Lake likely increased substantially on that date (fig. 11). The arrival of the bloom farther downstream at Cook Park (RM 9.9) and Oswego Dam (RM 3.4), again based on DO data, corresponds well with the estimated travel times between those sites (fig. 15). In addition, USGS monitoring data showed nothing unusual in Rock, Dairy, Gales, or Scoggins Creeks during this period, which further supports the evidence implicating Wapato Lake as the cause of the bloom.

Data from the USGS continuous monitor in the Tualatin

River near Scholls (RM 24.5) for 1997-2012 show that, except for 2008, photosynthetic production of DO by algae never has been high enough to achieve supersaturated conditions at that site (fig. 14). In 2008, however, supersaturated DO conditions occurred at the RM 24.5 site during most of July and extending into early August, peaking at greater than 140 percent of saturation in late July. Under normal conditions, small populations of algae enter the reservoir reach from upstream. The decreased shading (more light) in the reservoir reach causes the algae to grow faster, and a bloom may reach substantial levels by the time it travels downstream as far as RM 16.2 or farther. These anomalous conditions at RM 24.5 clearly indicated that a well-developed algal bloom was entering the reservoir reach from upstream, rather than developing within the reservoir reach.
The 2008 Tualatin River algal bloom was anomalous in many ways, but particularly because it included high-biomass conditions farther upstream than in normal years. At Rood Bridge (RM 38.4), the median and maximum chlorophyll- $a$ concentrations in July were greater than $30 \mu \mathrm{g} / \mathrm{L}$ and nearly $50 \mu \mathrm{g} / \mathrm{L}$ in 2008 (fig. 16A), respectively, whereas values at that location were less than $5 \mu \mathrm{g} / \mathrm{L}$ in July 2005-07. At Highway 219 (RM 44.4), chlorophyll- $a$ concentrations in 2008 were similar to those at Rood Bridge (table 5). Farther upstream, total chlorophyll concentrations in Wapato Creek at Gaston Road were substantially higher than at other sites in the upper Tualatin River basin in June and July (table 4), with median and maximum values of 190 and $675 \mu \mathrm{g} / \mathrm{L}$, respectively. In late July, elevated total chlorophyll levels (13-37 $\mu \mathrm{g} / \mathrm{L}$, table 4) also were measured in the Tualatin River at Dilley (RM 58.8) and at the Spring Hill pumping plant (RM 56.1). Total chlorophyll measurements at other sites upstream of the Spring Hill pumping plant, including the Tualatin River upstream of the Wapato Creek confluence and other tributary streams, clearly show that the Wapato Lake discharge had the greatest influence on chlorophyll levels at the Spring Hill pumping plant (table 4). In August, measured chlorophyll concentrations in Wapato Creek at Gaston Road decreased to the 10-14 $\mu \mathrm{g} / \mathrm{L}$ range as pumping of the lake decreased and stopped. All these data confirm that Wapato Lake discharges were a source of high-chlorophyll water that affected chlorophyll levels downstream all the way into the reservoir reach.

Unusually high total phosphorus concentrations also occurred in July 2008 at all sites from Dilley (RM 58.8) downstream to the reservoir reach (fig. 16B, table 5), and those values were consistent with high total phosphorus concentrations discovered in Wapato Lake drainage water on July 19 (table 7). The phosphorus data indicate that the increase in concentration in the Tualatin River occurred between the Cherry Grove (RM 67.8) and Dilley (RM 58.8) sampling sites, a reach that includes inputs from Wapato and Scoggins Creeks. Data from CWS showed low concentrations in Scoggins Creek and Henry Hagg Lake. A mass balance of total phosphorus loads in the Tualatin River between Cherry Grove and Dilley indicates that the Wapato Lake discharge can account for most or all of the increase in phosphorus in that river reach, assuming that the total phosphorus concentration of $2.5 \mathrm{mg} / \mathrm{L}$ in the Wapato Creek sample from July 19 was representative, and that Wapato Lake pumping rates were similar to those estimated in the analysis shown in figure 11. Using a flow of about $21 \mathrm{ft}^{3} / \mathrm{s}$ (about 72 percent of the full pumping capacity) from Wapato Creek, phosphorus inputs from Wapato Lake would have accounted for about 83 percent of the total phosphorus load in the Tualatin River at Dilley on July 19, with Scoggins Creek contributing about 8 percent and the upper Tualatin River just 2 percent. 


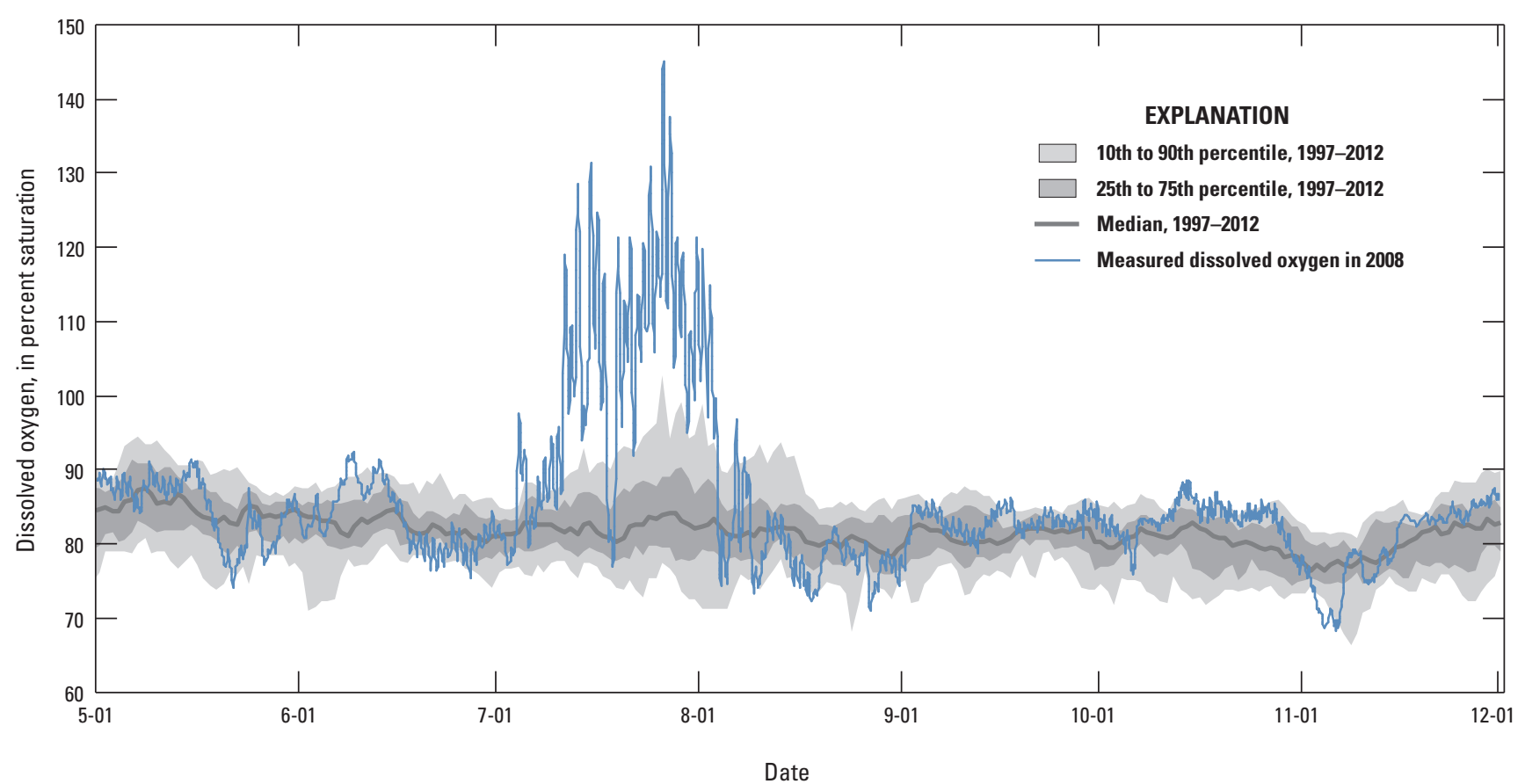

Figure 14. Comparison of measured dissolved oxygen percent saturation in the Tualatin River near Scholls, Oregon (river mile 24.5) in 2008 with long-term conditions in 1997-2012.

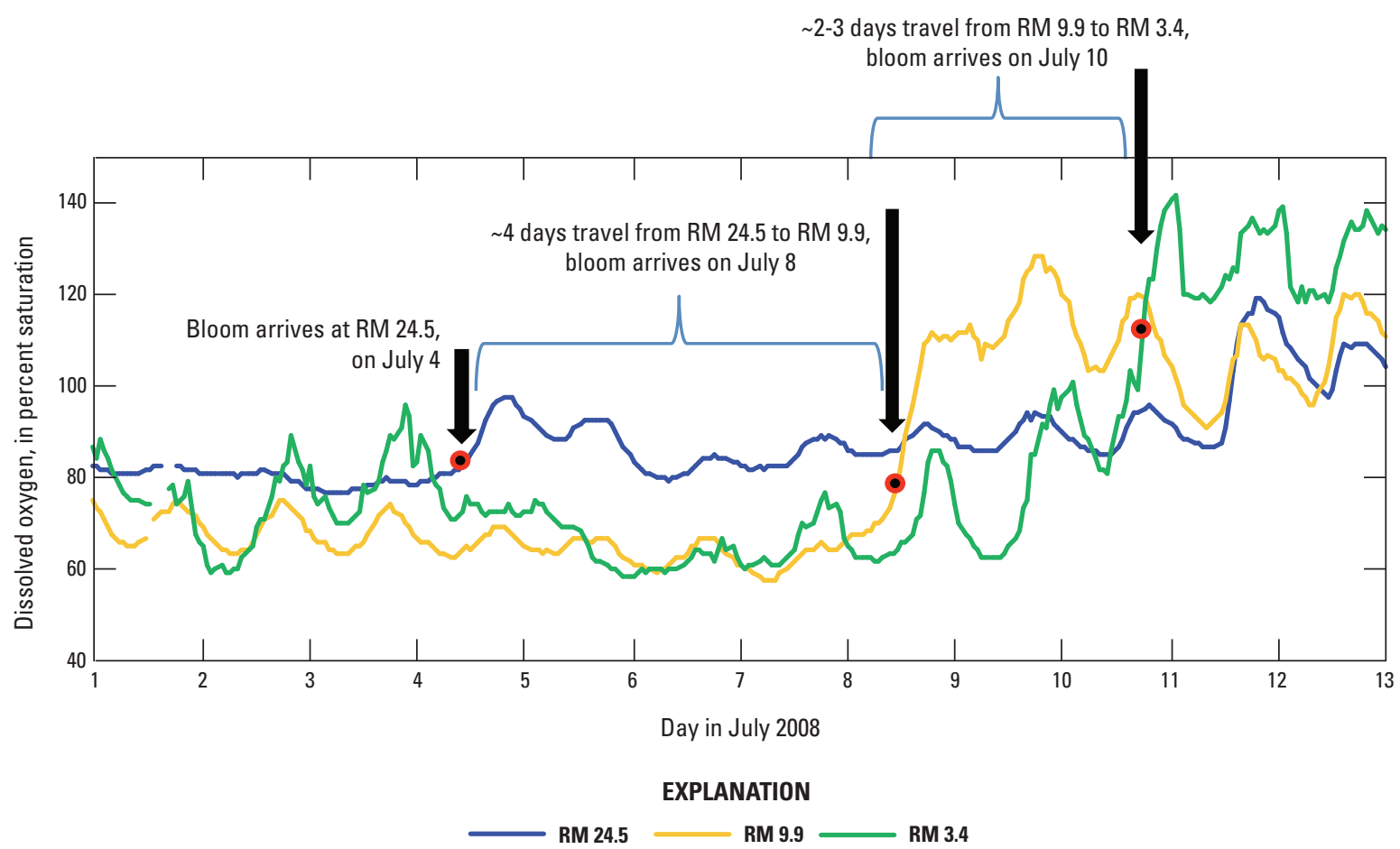

Figure 15. Dissolved-oxygen percent saturation in the Tualatin River at river miles (RM) 24.5, 9.9, and 3.4, showing a substantial increase in dissolved oxygen associated with the arrival of the Anabaena bloom at each location, Tualatin River, Oregon, July 2008. Arrows and red dots indicate when the dissolved oxygen signals reached each monitoring location. 

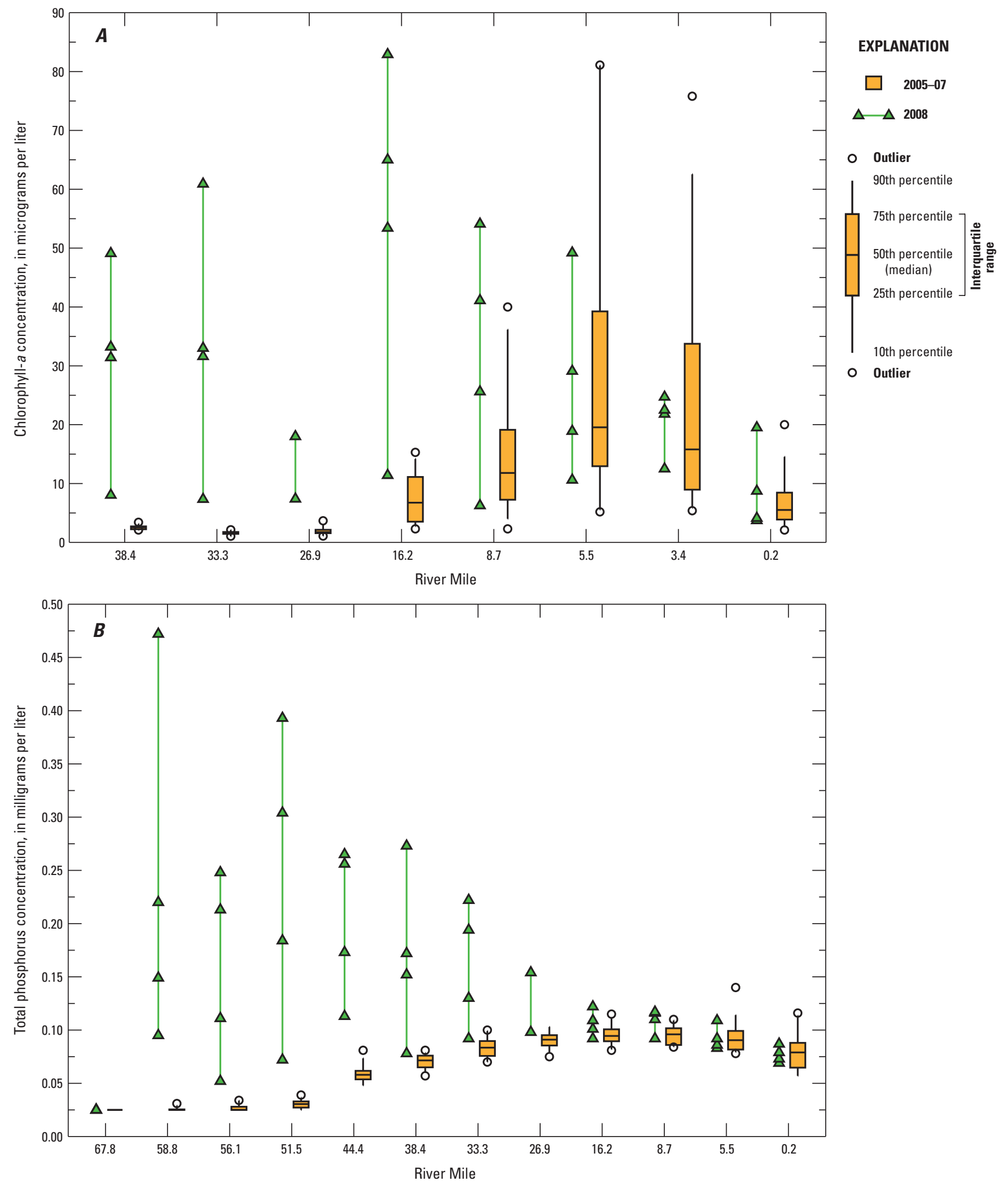

Figure 16. Comparison of $(A)$ chlorophyll- $a$ and $(B)$ total phosphorus concentrations in the Tualatin River, Oregon, July 2005-07 and July 2008. 
The abundance of zooplankton (particularly copepods, table 9), in addition to elevated nutrient concentrations, likely was important in producing conditions that led to the dominance of blue-green algae in the lower Tualatin River during July 2008. Blue-green algal colonies are not easily consumed by zooplankton because of their large size and mucilaginous coatings (Caramujo and others, 2008). Preferential grazing of diatoms and other non-blue-green algae by zooplankton would have reduced competition and allowed blue-green algae to proliferate (Gulati and DeMott, 1997). The mid-July increase in copepods (Carpenter and Rounds, 2013, figs. 17 and 18) was due to a large abundance of cyclopoid copepods and Diacyclops thomasi that coincided with the bloom (table 9). The cyclopoid copepods, in particular, had a strong reproductive pulse in the deepest green samples containing the greatest abundance of algae (Alan Vogel, ZP's Taxonomic Services, written commun., 2008). The algal bloom peaked in mid-July, with the highest measured biomass of $82.9 \mu \mathrm{g} / \mathrm{L}$ chlorophyll- $a$ at Elsner (RM 16.2) on July 14 (figs. 10, 13B, 16A, table 5). By July 16, zooplankton counts downstream of Elsner were exceptionally high (88,000 organisms per $\mathrm{m}^{3}$ ) and samples were composed mostly of copepods.

The algal bloom in the lower Tualatin River ended soon after pumping from Wapato Lake mostly ceased (large pump turned off) at the end of July (fig. 11), as evidenced by a return to normal DO conditions at the water-quality monitor at RM 24.5 about 5 days later (fig. 14, table 3). Samples collected by ODEQ on August 1 confirmed that water-quality conditions had returned to more-normal levels in Wapato Creek and the Tualatin River at Dilley (table 10). The public health advisory was lifted July 25 after it was evident that Anabaena concentrations in the lower Tualatin River had decreased substantially (table 6).

\section{Upstream Factors Affect Downstream Tualatin River Algae}

Previous research and modeling of the Tualatin River had determined that the most important factors affecting algae in the lower river included streamflow (residence time), light, water temperature, and, to a lesser degree, phosphorus concentrations (Rounds and others, 1999; Rounds, 2002). Although these factors continue to be important, the 2008 Wapato Lake algae bloom was instrumental in the identification of another important factor: the input of an upstream algal inoculum (Carpenter and Rounds, 2013). Upstream inocula were determined to be important in the San Joaquin River, California, where input of algal cells from upstream agricultural sloughs influenced phytoplankton assemblages in the slower-moving reach downstream (Leland and others, 2001). Similarly, the type and amount of algae and zooplankton that enter the reservoir reach of the Tualatin River are critical in determining how much and what types of algae will grow in the reservoir-like reach downstream to the Oswego Dam at RM 3.4.

Inputs of algal inoculum and zooplankton from upstream, as occurred during the 2008 Wapato Lake bloom, clearly can have a profound influence on plankton communities that develop in the lower Tualatin River. The DO data from the RM 24.5 site (fig. 14) showed that an algal bloom was already well developed upstream of that site in July 2008-something that had not occurred at any time since that monitor was installed in 1997 and has not occurred since (through 2015). Typically, algae do not have enough time to grow from a small population entering the reservoir reach (RM 30) before being transported downstream to the monitor location at RM 24.5. Algal growth in the reservoir reach normally does not become

Table 10. Water-quality data from the Oregon Department of Environmental Quality for selected sites in the upper Tualatin River basin, Oregon, August 2008.

[Data reproduced from Oregon Department of Environmental Quality (2008). Wapato C reek at Gaston R oad: Site includes discharge from the Wapato Lake pump station and the adjacent canal. Abbreviations: Hwy, highway; RM, river mile; ${ }^{\circ} \mathrm{C}$, degrees Celsius; $\mu \mathrm{S} / \mathrm{cm}$, microsiemens per centimeter; mg/L, milligrams per liter]

\begin{tabular}{|c|c|c|c|}
\hline Parameter & $\begin{array}{c}\text { Tualatin River at } \\
\text { Old Hwy } 47 \text { Bridge } \\
\text { near Gaston } \\
\text { (RM 62.3) }\end{array}$ & $\begin{array}{l}\text { Wapato Creek } \\
\text { at Gaston Road }\end{array}$ & $\begin{array}{c}\text { Tualatin River at } \\
\text { Dilley (downstream } \\
\text { of the Wapato Creek } \\
\text { confluence) (RM 58.8) }\end{array}$ \\
\hline Water temperature, ${ }^{\circ} \mathrm{C}$ & 15.5 & 17.3 & 10.3 \\
\hline Specific conductance, $\mu \mathrm{S} / \mathrm{cm}$ & 77 & 82 & 71 \\
\hline Dissolved oxygen, mg/L & 8.8 & 7.1 & 11.2 \\
\hline Dissolved oxygen, percent saturation & 87 & 73 & 100 \\
\hline $\mathrm{pH}$, standard units & 7.5 & 7.2 & 7.3 \\
\hline Total phosphorus, mg/L & 0.01 & 0.09 & 0.09 \\
\hline Ammonia-nitrogen, mg/L & $<0.02$ & 0.15 & $<0.02$ \\
\hline Nitrate-nitrogen, mg/L & 0.08 & 0.09 & $<0.005$ \\
\hline Pesticide screens & Negative $^{1}$ & Negative $^{1}$ & Negative $^{1}$ \\
\hline
\end{tabular}

${ }^{1}$ All three samples were negative, so no further tests were run. 
substantial until approximately the Elsner site (RM 16.2), which is about 2 days travel time downstream of the RM 24.5 site. Discharges from Wapato Lake on July 19, 2008, included extremely high chlorophyll- $a$ concentrations (330 $\mu \mathrm{g} / \mathrm{L}$, table 7) and high zooplankton populations (table 9), both of which likely had a large influence on the composition and size of the algal community that was transported downstream and entered the reservoir reach of the river.

Although large inputs of potentially toxic blue-green algae are clearly undesirable, some amount of algal inoculum delivered to the reservoir reach-preferably in the form of diatoms and other beneficial types of algae - is necessary to "seed" the river and thereby develop enough biomass and produce enough oxygen through photosynthesis to prevent low-DO conditions in the lower river (Carpenter and Rounds, 2013). Inclusion of this upstream inoculum factor into water-quality models could improve how well such models capture the size of the phytoplankton population in the river and, therefore, improve the accuracy of their predictions. For example, incorporating this upstream factor into the USGS neural network water-quality model of Tualatin River DO concentrations (Rounds, 2002) would likely improve its predictions and resolve any important year-to-year or seasonto-season variations in the size of the algal community. The importance of these upstream data, perhaps as manifested in chlorophyll concentrations upstream of the reservoir reach, also has ramifications for future monitoring plans.

\section{Implications for Monitoring and Management}

Blooms of nuisance and potentially toxic and harmful blue-green algae have occurred in the Tualatin River from time to time since the 1960s (Carpenter and Rounds, 2013, table 1). These blooms can cause problems for aquatic life in the river by producing high $\mathrm{pH}$ conditions and low DO concentrations, and may represent a risk to public health, depending on the composition and characteristics of the bloom. Some of the implications of algal blooms for monitoring and management are discussed below.

\section{Public Health Hazards}

In the event that blue-green algal blooms produce liver or neurotoxins (microcystins and anatoxin, for example), they may pose a public health risk to humans and wildlife. Blue-green algae blooms have the greatest potential to cause hazardous conditions for dogs, in particular, and humans when coming into contact with floating mats of high-concentration surface scums, such as during the 2008 Tualatin River bloom in the lower river reaches (figs. 8,10 ). Because of the extensive Anabaena surface scums in July 2008, the Oregon Department of Human Services issued a public health advisory for the lower Tualatin River. Anabaena cell counts were about $3,000-5,500$ cells/mL in Wapato Lake pump discharge in late July, whereas concentrations in the Tualatin River downstream were much higher, about 11,700 cells/mL at Rood Bridge (RM 38.4) on July 15 and 33,800 cells/mL on July 16 at Jurgens Park (RM 10.8) (table 6, fig. 13A). Health advisories typically are issued in Oregon when the combined cell counts from potentially toxigenic algae exceed 100,000 cells/mL or when extensive surface scums are present (Oregon Health Authority, 2010). Although the cell counts from this event did not reach the 100,000 cells/mL threshold, visible surface scums of Anabaena were present during the 2008 bloom. The health advisory was lifted on July 25, 2008, after the floating mats had largely disappeared and sufficient time was allowed for any toxins that may have been present to dissipate.

In addition to water-contact issues, studies have detected the presence of algal toxins in crops that were irrigated with water containing toxic blue-green algae (Milligan, 2009). This represents another potential exposure pathway to humans, and one that might merit further study in the future.

Anabaena is known to produce a potent nerve toxin (anatoxin- $a$ ) and liver toxins (microcystins). Although tests were not conducted for the more toxic anatoxin- $a$, microcystin was detected by USGS in a few Tualatin River samples at concentrations ranging from 0.14 to $2.4 \mu \mathrm{g} / \mathrm{L}$ (table 6). At the time of this study, the EPA had not set any health guidelines or concentration restrictions on algal toxins in drinking water. One detection of microcystin in the lower river, well downstream of drinking water intakes, exceeded the World Health Organization drinking water guideline of $1 \mu \mathrm{g} / \mathrm{L}$ (table 6). None of the samples exceeded the Oregon recreational health-hazard guideline for microsystins in effect at that time $(8 \mu \mathrm{g} / \mathrm{L})$. When surface scums are present or blue-green cell concentrations are high, river managers and public-health agencies may need to act swiftly to determine the presence and concentrations of any algal toxins and communicate the results to water users.

\section{Municipal Water Issues}

The 2008 Wapato Lake algae bloom was an important reminder that proactive engagement in the watershed is important. JWC expended more than $\$ 300,000$ in extra treatment costs during summer 2008, mainly associated with the need to add powdered activated carbon to resolve tasteand-odor issues. JWC also donated services and materials to the Wapato Improvement District to fully repair the Wapato Lake levee. 
A massive communications effort began to inform JWC's more than 300,000 customers that the drinking water, although it had a foul taste and odor, was not a health risk. During this event, hundreds of customer complaints were received, several press releases were issued, interviews were granted, and print and television stories ran. JWC also serves several high-tech industries that rely on consistent water quality, and those customers required specialized communications and information sharing. Several of these industries had production issues during this event, and it is unclear whether the geosmin, powdered activated carbon, or a combination of the two contributed to the problems.

After the 2008 algae bloom, a broad coalition of managers and regulators crafted a water-quality management plan for the Wapato Lake area that requires any major pumping from the lake to be completed by May 1 of each year. This limit was set in an effort to prevent ponded conditions during warm weather that facilitate the growth of large amounts of algae that might be pumped downstream (Oregon Department of Environmental Quality, 2009). Better communication among the various parties, data transmission showing when the Wapato pumps are operating, and realtime monitoring of organic-matter concentrations and other parameters at the JWC WTP have improved the real-time management of drinking-water quality. Prior to the 2008 Wapato Lake algae bloom, JWC had a proactive watershed monitoring program, but since then JWC has become more active in identifying and monitoring upstream threats to source water quality.

Organic carbon from peat soils and algae blooms can be another threat to drinking-water quality because organic matter in some WTPs has been associated with the formation of toxic disinfection by-products such as chloroform. JWC and its partner agencies closely monitor their water for various disinfection by-products at the WTP and within the drinking-water distribution system. In 2008, JWC modified the treatment process to decrease contact time between any organic matter and chlorine, which resulted in a decrease in disinfection by-product levels in the finished water. JWC has been monitoring the upper Tualatin River basin for precursors to disinfection by-product formation since 2007 to alert and inform WTP operators and water-quality staff.

\section{Wetland Management}

Draining seasonal wetlands such as Wapato Lake has the potential to negatively affect downstream water quality. The specific effects depend on a number of factors including the amount, timing, and quality of the discharge, as well as the flow or dilutive capacity of the receiving river at the time of discharge. Although draining of Wapato Lake typically is done during winter and spring when Tualatin River flows are high, delays until summer such as what occurred in 2008 can cause a myriad of problems for water users. To avoid similar events in the future, it is important to better understand the processes and conditions that combine to cause large algal blooms as well as high concentrations of organic carbon and nutrients in wetlands like Wapato Lake, and then to ensure that management options exist to avoid discharging such water downstream to the Tualatin River.

In 2010, a group of agencies came together to help avert a potential repeat of the water-quality issues attributed in 2008 to Wapato Lake. During winter of 2010, the largest pump at the Wapato Lake pump house was inoperable and the capacity of the smaller pump was insufficient to pump out the lake before summer. To avoid a repeat of the 2008 event, the lake had to be drained by May 1 , before favorable bloom conditions (low flows and warm weather) could develop. To accomplish this, extra pumps from CWS, the U.S. Army Corp of Engineers, and the City of Portland were used over the course of 2 months to drain Wapato Lake. Conditions were monitored closely by CWS, JWC, USGS, TVID, ODEQ, U.S. Fish and Wildlife Service, and others, and no significant bloom occurred that year (Bonn, 2010; U.S. Geological Survey, 2010).

The source of the nitrogen and phosphorus that fueled the 2008 Wapato Lake bloom includes groundwater seepage, agricultural fertilizer, and nutrients leached from the rich wetland soils. Peat soils typically contain large quantities of carbon, nitrogen, and phosphorus, which is stored in the accumulated soil biomass (Snyder and Morace, 1997). When these soils are drained, or particularly when drained and tilled, the organic matter oxidizes and liberates the carbon, nitrogen, and phosphorus, which then can affect water quality through stimulation of algal growth.

The oxidation of peat soils also can result in general land subsidence in which a large mass of the soil profile essentially disappears through decomposition of accumulated organic matter (Snyder and Morace, 1997). This type of subsidence has occurred at Wapato Lake, resulting in an unquantified amount of subsidence that is likely several feet, but possibly as much as $6-8 \mathrm{ft}$ (Christy, 2015). As a result, the land surface is lower and would hold a deeper lake now compared to the period prior to 1895 when the lake was first drained. This change in the land surface may present some challenges and opportunities for future management and restoration of the Wapato Lake area.

Wetlands can be used effectively to improve water quality, removing nutrients and suspended sediment if managed properly. The U.S. Fish and Wildlife Service is working to determine effective strategies for the future restoration and management of the Wapato Lake area. The fact that wetland discharges can have both positive and negative effects on the Tualatin River suggests that enhanced and coordinated management of publicly owned wetlands at Wapato Lake, Jackson Bottom, Fernhill Wetlands, and (or) the wetlands of the Tualatin River National Wildlife Refuge may be beneficial to all. Management of wetlands to provide a beneficial algal inocula (diatoms, for instance) to the Tualatin River could also provide benefits downstream by enhancing food webs and providing some photosynthetic oxygen production while avoiding the problems associated with bluegreen algae. 


\section{Managing Dissolved Oxygen}

Although excessively large algal blooms are not desirable and may contribute to violations of water-quality standards, some level of algal biomass and photosynthesis is critical for sustaining food webs and minimum DO concentrations in the Tualatin River. When algal biomass declines and photosynthetic production of oxygen decreases, oxygen demands and high water temperatures often combine to produce low DO concentrations in the lower Tualatin River that sometimes do not meet State of Oregon water-quality standards, a condition that may last for weeks or even months during the low-flow period (Carpenter and Rounds, 2013).

The discharge permit for CWS treatment facilities requires CWS to consider instream DO concentrations as feedback to their allowable discharge limits throughout the critical summer season. If weekly mean DO levels decrease to less than $6.7 \mathrm{mg} / \mathrm{L}$ in the lower river, CWS managers must meet stringent ammonia treatment levels at the WWTFs because the river has little ability to assimilate ammonia loads when DO concentrations are low. For water-quality management purposes, CWS has some flexibility to release relatively cool, high-quality water from upstream reservoirs to mitigate water-quality problems in the lower river. For example, CWS uses higher streamflow targets for flow augmentation (upstream reservoir releases) during late summer and early autumn to offset the anticipated effects of oxygen demands and potential low-DO conditions late in the low-flow season. Once it became clear that the 2008 algal bloom was severe, CWS increased its upstream reservoir releases to increase the percentage of flow augmentation water in the river. Although it was critical in 2008 to increase river flow to flush out the hazardous blue-green algae, such reservoir releases also dilute any beneficial phytoplankton populations and can thereby impede the recovery of photosynthesis and DO production that is critical for offsetting sediment oxygen demands (Carpenter and Rounds, 2013). In the Tualatin River system, a delicate balance exists between flow management, natural flow, algal growth and photosynthesis, DO concentrations, and general water quality.

\section{Water-Quality and Plankton Monitoring and Models}

The 2008 Wapato Lake algae bloom presents an opportunity to evaluate the current monitoring strategy and network for detecting similar problems, should they occur in the future. Although the existing data-collection network provided the necessary information to hone in on the source of the 2008 bloom, now that it is apparent that the plankton community in the upper basin can have profound effects on downstream populations, additional monitoring in the upper part of the basin may be warranted. Plankton monitoring has not been done in the upper reaches (upstream of RM 38.4) of the Tualatin River in recent years, mainly because algal densities tend to be small there, but now it is clear that such monitoring would help to track algal population levels seasonally and longitudinally. JWC has begun quarterly plankton monitoring at several sites in the upper Tualatin River basin between Gaston and the Spring Hill pumping plant. Perhaps the results of that type of monitoring could be used to trigger more extensive monitoring and sample collection when necessary.

One of the best ways to improve the accuracy and predictive capabilities of water-quality models of the lower river is to better define the size and type of the plankton community entering the reservoir reach from upstream sources such as wetlands, reservoirs, and other habitats. The primary objective of such monitoring would be to better understand the type and amount of algae being delivered to the reservoir reach. Similar plankton sampling could be conducted at nursery ponds, wetlands, and other water bodies that may discharge to the Tualatin River, especially ones with a history of algal blooms.

Another valuable monitoring strategy would be the addition of total chlorophyll to the suite of parameters monitored continuously in the Tualatin River near Scholls (RM 24.5) or even farther upstream at Spring Hill (RM 56.1). In fact, JWC began monitoring a suite of parameters in their raw water from the Tualatin River at the Spring Hill pumping plant after the 2008 event, including chlorophyll. It is possible to use chlorophyll data from well-calibrated instream sensors to determine when a water sample should be collected and analyzed for plankton communities; such sensors may provide the necessary and timely information on the amount and type of algae arriving at drinking-water intakes or entering the reservoir reach of the river so that flow management and other strategies can be fine-tuned.

\section{Summary and Conclusions}

During July 2008, a large bloom of Anabaena flos-aquae (primarily) and Aphanizomenon flos-aquae occurred in the lower Tualatin River, prompting the Oregon Department of Human Services (now the Oregon Health Authority) to issue a public health advisory for recreational water contact on July 12 for the reach extending from Jurgens Park (RM 10.8) to the river mouth. This bloom formed a thick surface scum along the margins and backwater areas of that reach. Anabaena can produce potent nerve and liver toxins (anatoxin- $a$ and microcystin), and although tests were not performed for the more toxic compound (anatoxin- $a$ ), microcystin was detected at concentrations ranging from 0.14 to $2.4 \mu \mathrm{g} / \mathrm{L}$ in the lower river. At the same time in June and July, taste and odor issues due to geosmin occurred in municipal water produced by the Joint Water Commission from water withdrawn from the upper Tualatin River at RM 56.1. Extra treatment with powdered activated carbon was added at the water treatment plant, and upstream monitoring was enhanced to identify the source of the issues. 
After reports of the taste-and-odor issues and discovery of the bloom in the lower river-and on the basis of water sample data, continuous monitoring data, estimated travel times, and mass balance calculations - the source of the waterquality problems was traced upstream to the Wapato Lake agricultural area adjacent to and southeast of Gaston, Oregon, in the upper part of the Tualatin River basin. Because of a breach in one of the Wapato Lake levees during a December 2-3, 2007 storm, the low-lying area was flooded to a much greater extent than normal and could not be drained until summer after water levels receded or until the levee was patched. Normally, the lake would have been pumped out in spring so that the lakebed could be farmed in summer. Drainage water entering the Tualatin River through Wapato Creek at RM 60.1 had elevated concentrations of organic matter and phosphorus and contained a rich inoculum of algae including Anabaena flos-aquae and Aphanizomenon flos-aquae. Wapato Lake discharges also contained high abundances of zooplankton (primarily copepods) that continued to thrive and multiply downstream in the lower Tualatin River during the bloom, likely affecting the algal population through selective grazing and resulting in strong dominance by blue-green algae.

The 2008 Wapato Lake algal bloom demonstrated the importance of upstream factors in influencing downstream water quality in the Tualatin River. Although the algal biomass in the upper river may not have been exceptionally high, the bloom multiplied as it traveled downstream, reaching more than 33,000 cells/mL of Anabaena flos-aquae and more than $80 \mu \mathrm{g} / \mathrm{L}$ chlorophyll- $a$ in the reservoir-like section of the lower river where conditions for algal growth are more favorable. Clearly, the amount and type of plankton entering this reachin addition to flow, light, temperature, and nutrients - are important in determining the type and amount of algae that grow in the lower river where the photosynthetic production of DO is critical for maintaining minimum oxygen levels.

Future monitoring of potential plankton inocula sources in the upper part of the Tualatin River basin using continuous monitoring and targeted sampling for chlorophyll and species identification could inform predictive models and enhance the real-time network to give water-quality managers additional time to respond to events similar to the 2008 Wapato Lake algae bloom. Current management and future restoration of the Wapato Lake area by the U.S. Fish and Wildlife Service will benefit from the lessons learned from the 2008 events. Given the potential importance of wetlands as sources of plankton to downstream river reaches, it may be helpful for managers of these resources to share information and potentially coordinate their management of the many wetlands in the Tualatin River basin, to help prevent future problems associated with bluegreen algae blooms and to enhance water quality throughout the river system.

\section{Acknowledgments}

This study was completed as part of a long-term scientific collaboration between USGS and Clean Water Services (CWS). The authors thank the staff of the CWS WaterQuality Laboratory for collecting samples and producing data that were helpful to this study. Deanna Conners and Ken Kauffman at the Oregon Department of Human Services, Public Health Division, provided useful information and expertise on blue-green algae and potential threats to public health. Brian Wegener and several volunteers from the Tualatin Riverkeepers helped to document the Anabaena bloom with photographs and observations, and disseminated valuable information to the public regarding the potential health hazards of the bloom. Conversations with Alan Milligan (Oregon State University) were helpful for understanding additional public health issues related to algal toxins. Thanks also to all of the people and organizations that came together to address the problems associated with the 2008 Wapato Lake algae bloom.

\section{References Cited}

American Public Health Association, 1992, Standard methods for examination water and wastewater (17th ed.): Washington, D.C., American Public Health Association, American Water Works Association, and Water Environment Federation [variously paged].

Berger, C.J., 1993, Water quality modeling of the Tualatin River: Portland, Oreg., Portland State University, M.S. Thesis, Technical Report EWR-001-94, 152 p.

Bonn, B.A., 2008, 2008 Annual Report-Tualatin River Flow Management Technical Committee: Prepared for Clean Water Services and Oregon Water Resources Department, District 18 Watermaster, 42 p. plus appendixes, accessed April 24, 2013, at http://www.co.washington.or.us/ Watermaster/SurfaceWater/tualatin-river-flow-technicalcommittee-annual-report.cfm.

Bonn, B.A., 2010, 2010 Annual Report-Tualatin River Flow Management Technical Committee: Prepared for Clean Water Services and Oregon Water Resources Department, District 18 Watermaster, 42 p. plus appendixes, accessed April 24, 2013, at http://www.co.washington.or.us/ Watermaster/SurfaceWater/tualatin-river-flow-technicalcommittee-annual-report.cfm. 
Bonn, B.A., and Rounds, S.A., 2010, Use of stable isotopes of carbon and nitrogen to identify sources of organic matter to bed sediments of the Tualatin River, Oregon: U.S. Geological Survey Scientific Investigations Report 2010-5154, 58 p. [Also available at http://pubs.usgs.gov/ $\operatorname{sir} / 2010 / 5154 /$.

Caramujo, M., Boschker, H.T.S., and Admiraal, W., 2008, Fatty acid profiles of algae mark the development and composition of harpacticoid copepods: Journal of Freshwater Biology, v. 53, p. 77-90.

Carpenter, K.D., and Rounds, S.A., 2013, Plankton communities and summertime declines in algal abundance associated with low dissolved oxygen in the Tualatin River, Oregon: U.S. Geological Survey Scientific Investigations Report 2013-5037, 76 p. [Also available at http://pubs.usgs. gov/sir/2013/5037/.]

Carter, L.M., Petersen, R.R., and Roe, D.K., 1976, An assessment of the effects of low-flow augmentation and improved sewage treatment on the lower reaches of the Tualatin River during the dry weather season of 1976: Portland, Oreg., Portland State University, Department of Environmental Sciences and Research, 85 p.

Cass P.L., and Miner, J.R., 1993, The historical Tualatin River Basin: Oregon Water Resources Research Institute, Oregon State University, Tualatin River Basin Water Resources Management Report Number 7, 59 p., accessed August 27, 2015, at https://ir.library.oregonstate.edu/xmlui/ handle/1957/735.

Christy, J.A., 2015, Historical conditions at Wapato Lake, Washington and Yamhill Counties, Oregon: Portland, Oreg., Portland State University, Oregon Biodiversity Information Center, Institute for Natural Resources, 7 p.

Clean Water Services, 2006, Clean Water Services Watershed Monitoring Plan: Hillsboro, Oreg., Clean Water Services, $53 \mathrm{p}$.

Clean Water Services, 2010, Wapato Lake-Protecting water quality while transitioning to a National Wildlife Refuge: Wapato Lake briefing paper, Clean Water Services, $4 \mathrm{p}$.

Fischer, W.J., Garthwaite, I., Miles, C.O., Ross, K.M., Aggen, J.B., Chamberlin, A.R., Towers, N.A., and Dietrich, D.R., 2001, Congener-independent immunoassay for microcystins and nodularins: Environmental Science and Technology, v. 35, p. 4849-4856.

Gottler, R., Calles, J., Westerhoff, P., and Abbaszadegan, M., 2007, Addressing concerns about tastes and odors and cyanotoxins in tap water: Denver, American Water Works Association Research Foundation, 132 p.
Green, G.L., 1982, Soil survey of Washington County, Oregon: U.S. Department of Agriculture, Soil Conservation Service, in cooperation with the Oregon Agricultural Experiment Station, 138 p. plus maps.

Gulati, R.D., and DeMott, W.R., 1997, The role of food quality for zooplankton-Remarks on the state-of-the art, perspectives and priorities: Journal of Freshwater Biology, v. 38, p. $753-768$.

Izaguirre, G., Hwang, C.J., Krasner, S.W., and McGuire, M.J., 1982, Geosmin and 2-methylisoborneol from cyanobacteria in three water supply systems: Applied and Environmental Microbiology, v. 43, p. 708-714.

Leland, H.V., Brown, L.R., and Mueller, D.K., 2001, Distribution of algae in the San Joaquin River, California, in relation to nutrient supply, salinity and other environmental factors: Freshwater Biology, v. 46, p. 1139-1167.

Milligan, A.J., 2009, Potential impact of cyanobacteria on crop plants, in Pscheidt, J.W., and Ocamb, C.M., eds., 2009 PNW Plant Disease Management Handbook: Extension Services of Oregon State University, Washington State University and University of Idaho, p. 38-39.

Oregon Department of Environmental Quality, 2008, Wapato Lake region water quality study report-August 1, 2008 sampling results: Portland, Oreg., Department of Environmental Quality, 9 p.

Oregon Department of Environmental Quality, 2009, Wapato Lake Water-Quality Management Plan (WQMP) for the Wapato Improvement District: Portland, Oreg., Department of Environmental Quality, 18 p.

Oregon Department of Environmental Quality and Unified Sewerage Agency, 1982, Tualatin River water quality 1970-1979—Appendices: Portland, Oreg., Department of Environmental Quality [variously paged].

Oregon Health Authority, 2010, Oregon Harmful Algae Bloom Surveillance (HABS) Program-Public health advisory guidelines, harmful algae blooms in freshwater bodies: Oregon Health Authority, 23 p., accessed April 17, 2013, at http://public.health.oregon.gov/HealthyEnvironments/ Recreation/HarmfulAlgaeBlooms/Documents/ HABPublicHealthAdvisoryGuidelines.10.10.12.pdf.

Risley, J., 2000, Effects of hypothetical management scenarios on simulated water temperatures in the Tualatin River, Oregon: U.S. Geological Survey Water-Resources Investigations Report 00-4071, Supplement to WaterResources Investigations Report 97-4071, 110 p. [Also available at http://or.water.usgs.gov/pubs_dir/Online/ Pdf/00-4071.pdf.] 
Rounds, S.A., 2002, Development of a neural network model for dissolved oxygen in the Tualatin River, Oregon, in Proceedings of the Second Federal Interagency Hydrologic Modeling Conference, July 29-August 1, 2002, Las Vegas, Nevada: Subcommittee on Hydrology of the Interagency

Advisory Committee on Water Information, 13 p., accessed December 16, 2013, at http://or.water.usgs.gov/tualatin/ ann_proceedings.pdf.

Rounds, S.A., and Doyle, M.C., 1997, Sediment oxygen demand in the Tualatin River basin, Oregon, 1992-96: U.S. Geological Survey Water-Resources Investigations Report 97-4103, 19 p. [Also available at http://pubs.er.usgs.gov/ publication/wri974103.]

Rounds, S.A., and Wood, T.M., 2001, Modeling water quality in the Tualatin River, Oregon, 1991-1997: U.S. Geological Survey Water-Resources Investigations Report 01-4041, 53 p. [Also available at http://pubs.er.usgs.gov/publication/ wri014041.]

Rounds, S.A., Wood, T.M., and Lynch, D.D., 1999, Modeling discharge, temperature, and water quality in the Tualatin River, Oregon: U.S. Geological Survey Water-Supply Paper 2465-B, 121 p. [Also available at http://pubs.er.usgs.gov/ pubs/wsp/wsp2465B.]

Snyder, D.T., and Morace, J.L., 1997, Nitrogen and phosphorus loading from drained wetlands adjacent to Upper Klamath and Agency Lakes, Oregon: U.S. Geological Survey Water-Resources Investigations Report 97-4059, 67 p. [Also available at http://pubs.er.usgs.gov/ usgspubs/wri/wri974059.]

Sullivan, A.B., and Rounds, S.A., 2005, Modeling hydrodynamics, temperature and water quality in Henry Hagg Lake, Oregon, 2000-2003: U.S. Geological Survey Scientific Investigations Report 2004-5261, 38 p. [Also available at http://pubs.usgs.gov/sir/2004/5261/.]
U.S. Census Bureau, 2012, State and county quick facts for Washington County, Oregon: U.S. Census Bureau, accessed September 23, 2013, at http://quickfacts.census.gov/qfd/ states/41/41067.html.

U.S. Fish and Wildlife Service, 2007, Tualatin River National Wildlife Refuge Wapato Lake Unit additionLand conservation plan and environmental assessment: Portland, Oreg., U.S. Fish and Wildlife Service, 68 p. plus appendixes, accessed August 27, 2015, at http://www.fws. gov/pacific/planning/main/docs/OR/Wapato/Final\%20 LCP\%20EA/2\%20Wapato\%20FONSI\%20EA\%20LCP.pdf.

U.S. Geological Survey, 2010, USGS Data Grapher and Data Tabler: U.S. Geological Survey Web site, accessed December 12, 2012, at http://or.water.usgs.gov/grapher/.

U.S. Geological Survey, 2013, Standard Reference Sample project: U.S. Geological Survey Web site, accessed January 29, 2013, at http://bqs.usgs.gov/srs/.

U.S. Geological Survey, 2015a, National Water Information System-Current conditions for Oregon: U.S. Geological Survey data base, accessed August 27, 2015, at http:// waterdata.usgs.gov/or/nwis/current/?type=quality\&group_ key=huc_cd.

U.S. Geological Survey, 2015b, Tualatin River Basin Monitoring Sites: U.S. Geological Survey data base, accessed August 27, 2015, at http://or.water.usgs.gov/ tualatin/monitors/.

Wehr, J.D., and Sheath, R.G., eds., 2003, Freshwater algae of North America-Ecology and classification: San Diego, Calif., Academic Press, 918 p. 
Upstream Factors Affecting Tualatin River Algae, Oregon

This page left intentionally blank 







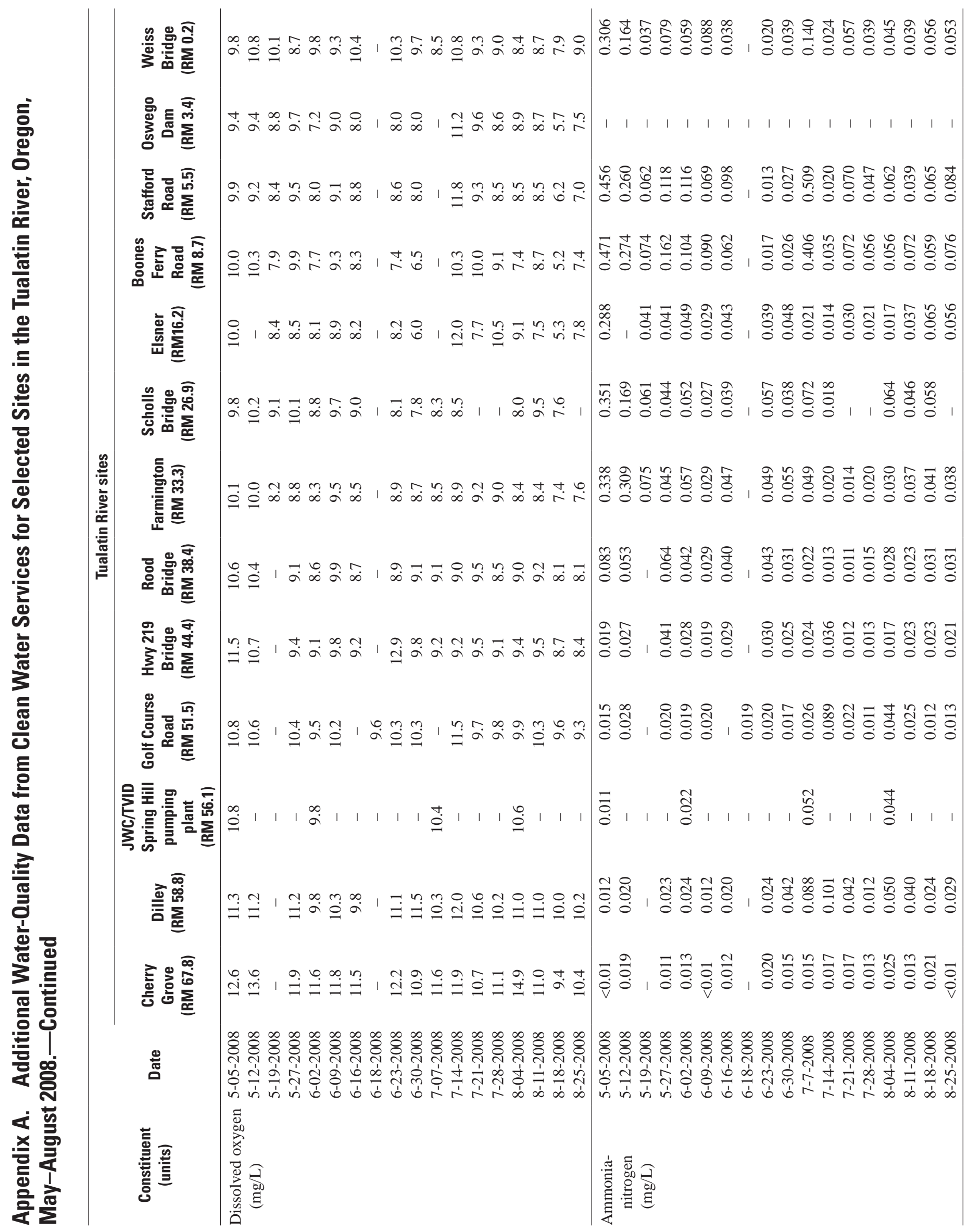




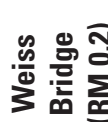
弄

힣 돈 む)

产

승 옹 ํํํ 政

กั

雪偪

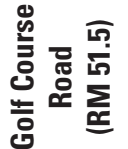

을 을

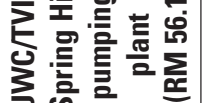
言离总

링 인

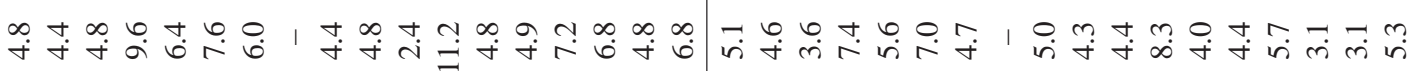

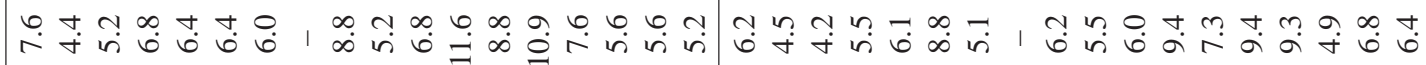

茂

金 |

๙

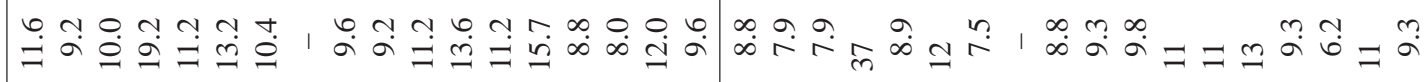

我号

过

我 $\stackrel{\circ}{\circ}$

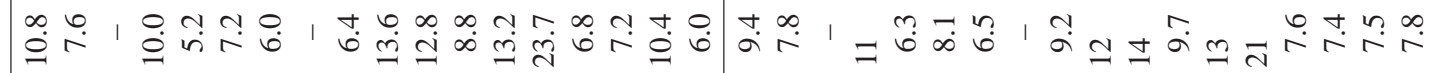
$\stackrel{\infty}{i}$

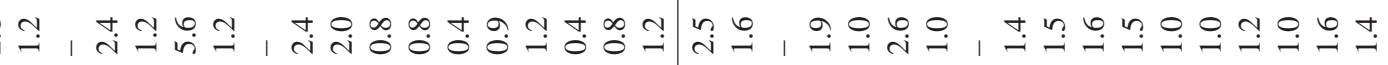

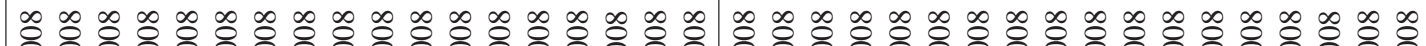
范

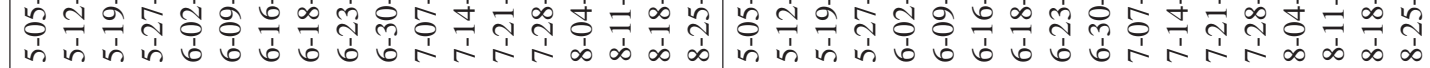

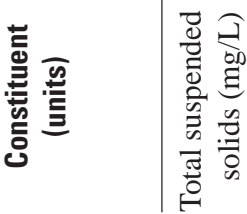


Upstream Factors Affecting Tualatin River Algae, Oregon

This page left intentionally blank 


\section{Appendix B. Biovolume of Algal Taxa in Water Samples Collected from Wapato Lake Pump Discharge and Downstream in the Tualatin River at the Spring Hill Pumping Plant, Oregon, July 19-21, 2008}

Taxon biovolumes in cubic microns per milliliter. A bbreviations: RM, river mile; sp, species; JWC, Joint Water Commission; TVID, Tualatin Valley Irrigation District.

\begin{tabular}{|c|c|c|c|c|}
\hline \multirow[t]{2}{*}{ Algal taxa } & \multirow[t]{2}{*}{ Algal group } & \multicolumn{2}{|c|}{$\begin{array}{l}\text { Wapato Lake pump discharge } \\
\text { (near Tualatin River at RM 60.1) }\end{array}$} & \multirow{2}{*}{$\begin{array}{c}\text { Tualatin River at the } \\
\text { JWC/TVID Spring Hill } \\
\text { pumping plant } \\
\text { (RM 56.1) } \\
\text { July } 21\end{array}$} \\
\hline & & July 19 & July 21 & \\
\hline Anabaena flos-aquae & Blue-green algae & 373,049 & 201,447 & 89,932 \\
\hline Aphanizomenon flos-aquae & Blue-green algae & 175,389 & 0 & 1,691 \\
\hline Cryptomonas erosa & cryptophyte & $3,619,136$ & $5,003,093$ & 418,786 \\
\hline Rhodomonas minuta & cryptophyte & 16,704 & 12,027 & 2,148 \\
\hline Cyclotella meneghiniana & Diatom & 0 & 114,253 & 10,201 \\
\hline Cyclotella pseudostelligera & Diatom & 0 & 76,219 & 1,745 \\
\hline Nitzschia acicularis & Diatom & 155,901 & 0 & 7,517 \\
\hline Nitzschia capitellata & Diatom & 0 & 324,720 & 38,657 \\
\hline Nitzschia palea & Diatom & 150,333 & 162,360 & 4,832 \\
\hline Stephanodiscus hantzschii & Diatom & 0 & 144,320 & 15,463 \\
\hline Phacus sp. & Euglenoid & 97,438 & 0 & 0 \\
\hline Trachelomonas hispida & Euglenoid & 584,630 & 631,400 & 56,375 \\
\hline Trachelomonas volvocina & Euglenoid & $3,673,423$ & 7,934,593 & 404,826 \\
\hline Actinastrum hantzschii & Green algae & 534,519 & 0 & 0 \\
\hline Ankistrodesmus falcatus & Green algae & 62,639 & 60,133 & 4,027 \\
\hline Chlamydomonas sp. & Green algae & 651,444 & 488,583 & 52,348 \\
\hline Crucigenia quadrata & Green algae & 0 & 25,557 & 2,282 \\
\hline Pediastrum duplex & Green algae & 0 & 81,781 & 0 \\
\hline Pediastrum tetras & Green algae & 0 & 72,160 & 0 \\
\hline Scenedesmus acuminatus & Green algae & 66,815 & 36,080 & 32,214 \\
\hline Scenedesmus quadricauda & Green algae & 537,442 & 234,520 & 65,784 \\
\hline Sphaerocystis schroeteri & Green algae & 155,901 & 0 & 22,550 \\
\hline Tetrastrum staurogeniaforme & Green algae & 60,133 & 0 & 5,799 \\
\hline Marssoniella elegans & Unknown & 0 & 541,200 & 96,643 \\
\hline Unidentified flagellate & Unknown & $1,876,383$ & $1,671,707$ & 5,369 \\
\hline Achnanthes minutissima & Diatom & 0 & 0 & 1,342 \\
\hline Euglena sp. & Euglenoid & 0 & 0 & 15,570 \\
\hline Gomphonema angustatum & Diatom & 0 & 0 & 4,832 \\
\hline Navicula graciloides & Diatom & 0 & 0 & 11,678 \\
\hline Nitzschia communis & Diatom & 0 & 0 & 1,208 \\
\hline Rhoicosphenia curvata & Diatom & 0 & 0 & 3,141 \\
\hline Scenedesmus sp. & Green algae & 0 & 0 & 5,369 \\
\hline Synedra rumpens & Diatom & 0 & 0 & 3,758 \\
\hline Trachelomonas cylindrica & Euglenoid & 0 & 0 & 21,476 \\
\hline Total abundance & & $12,791,279$ & $17,816,154$ & $1,407,563$ \\
\hline
\end{tabular}



Publishing support provided by the U.S. Geological Survey Science Publishing Network, Tacoma Publishing Service Center

For more information concerning the research in this report, contact the Director, Oregon Water Science Center

U.S. Geological Survey

2130 SW 5th Avenue

Portland, Oregon 97201

http://or.water.usgs.gov 
